\title{
Simulation chamber investigation of the reactions of ozone with short-chained alkenes
}

\author{
Robert Wegener, ${ }^{1}$ Theo Brauers, ${ }^{1}$ Ralf Koppmann, ${ }^{1,2}$ Sonia Rodríguez Bares, ${ }^{1}$ \\ Franz Rohrer, ${ }^{1}$ Ralf Tillmann, ${ }^{1}$ Andreas Wahner, ${ }^{1}$ Armin Hansel, ${ }^{3}$ and Armin Wisthaler ${ }^{3}$ \\ Received 19 May 2006; revised 31 August 2006; accepted 22 November 2006; published 3 July 2007.
}

[1] Reaction rate coefficients and product yields in the gas phase reaction of $\mathrm{O}_{3}$ with the short-chained alkenes ethene, propene, 1-butene, isobutene, $(E)$-butene, and $(Z)$-butene were determined by Simulation of Atmospheric Photochemistry in a Large Reaction Chamber (SAPHIR). In a first set of experiments, reaction rate coefficients were acquired in an absolute reaction rate study from the measured concentration time profiles of ozone and the alkenes with side reactions being suppressed by adding a radical scavenger. The rate coefficients obtained agree well with literature data; for all but one alkene, the deviation was less than $10 \%$. In a second set of experiments, $\mathrm{OH}$ yields were derived from the additional alkene turnover in the absence of a radical scavenger. In contrast to other studies, the $\mathrm{OH}$ yields determined in the dry chamber (propene, $0.10 \pm 0.07 ; 1$-butene, $0.00 \pm 0.08$, isobutene, $0.30 \pm 0.14 ;(Z)$-butene, $0.18 \pm 0.09$; and $(E)$-butene, $0.70 \pm 0.12$ ) differed from the yields obtained under humid conditions (propene, $0.30 \pm 0.08$; 1-butene, $0.30 \pm 0.09$; isobutene, $0.80 \pm 0.10$; $(Z)$-butene, $0.40 \pm 0.05$; and $(E)$-butene, $0.60 \pm 0.12$ ). The only exception was ethene ozonolysis, where no $\mathrm{OH}$ production was observed. $\mathrm{HO}_{2}$ yields (propene, $1.50 \pm 0.75 ; 1$-butene, $1.60 \pm 0.80$; and isobutene, $2.00 \pm 1.00$ ) estimated from the additional ozone turnover compared to the experiments where radicals were not scavenged are reported here for the first time. Furthermore, the yields of the stable ozonolysis products $\mathrm{CO}$, acetaldehyde, and formaldehyde were acquired by monitoring the concentration time profile of the respective compound.

Citation: Wegener, R., T. Brauers, R. Koppmann, S. Rodríguez Bares, F. Rohrer, R. Tillmann, A. Wahner, A. Hansel, and A. Wisthaler (2007), Simulation chamber investigation of the reactions of ozone with short-chained alkenes, J. Geophys. Res., 112, D13301, doi:10.1029/2006JD007531.

\section{Introduction}

[2] The mechanism of ozonolysis developed by Criegee [Criegee and Schröder, 1960] for reactions in the liquid phase is widely accepted for gas phase reactions. The ozonolysis is initiated by a [2+3]-cycloadditon of ozone to the alkene to form a 1,2,3-trioxolane or ozonide (reaction (1)). The ozonide rapidly decomposes by cleavage of a $\mathrm{C}-\mathrm{C}$ bond and an $\mathrm{O}-\mathrm{O}$ bond to release a primary carbonyl component and a carbonyl oxide, the Criegee intermediate (2).

[3] The distribution of the decomposition products can mostly be explained by electronic effects. After cleavage of the ozonide electron acceptor subsituents will be found in the carbonyl compound, while electron-donating substitu-

\footnotetext{
${ }^{1}$ Institut II: Troposphäre, Institut für Chemie und Dynamik der Geosphäre, Forschungszentrum Jülich, Jülich, Germany.

${ }^{2}$ Now at Fachbereich C, Mathematik und Naturwissenschaften, Atmosphärenphysik, Bergische Universität Wuppertal, Wuppertal, Germany.

${ }^{3}$ Institut für Ionenphysik, Universität Innsbruck, Innsbruck, Austria.

Copyright 2007 by the American Geophysical Union. 0148-0227/07/2006JD007531
}

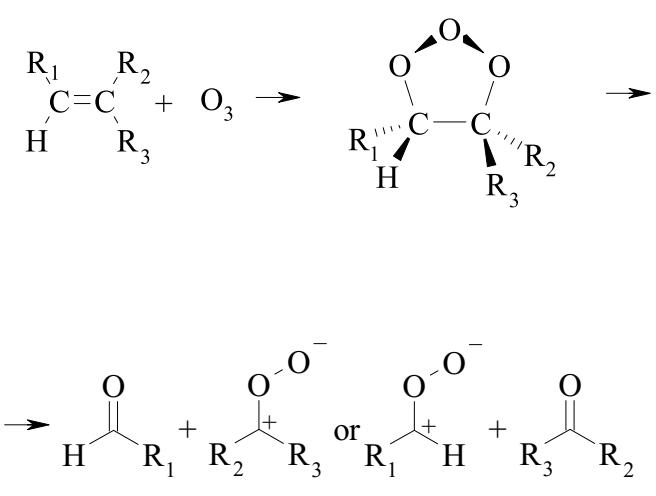

ents remain in the carbonyl oxides. This can be observed in ozonolysis of alkyl substituted alkenes, where the Criegee intermediates are more highly substituted than the carbonyls [Grosjean and Grosjean, 1996b; Tuazon et al., 1997].

[4] In solutions the carbonyl and the Criegee intermediate are held together by cage effects and recombine to an 1,2,4- 
trioxolane. In the gas phase the products separate. Because of the high exothermicity of the ozonide decomposition, the carbonyl compound and the Criegee intermediate are vibrationally excited. While the energy is not sufficient for the carbonyl to decompose, it sets up a competition between collisional deactivation and further reactions of the excited Criegee intermediate. Studies on the influence of pressure on the $\mathrm{OH}$ yields in ozonolysis reactions [Kroll et al., 2001] showed that at atmospheric pressure the majority of $\mathrm{OH}$ radicals is produced from thermalized Criegee intermediates.

[5] There are four possible pathways for the stabilized Criegee intermediate [Atkinson, 1997; Martinez and Herron, 1988; Niki et al., 1987]: (1) It may eject $\mathrm{O}\left({ }^{3} \mathrm{P}\right)$ to yield a carbonyl (oxygen-atom channel, reaction (3)), (2) react with water or other reactive species (reaction (8)), (3) form a hydroperoxide via a 1,4-hydrogen shift (hydroperoxide channel, reaction (4)) or (4) rearrange to an ester or an acid (ester channel, reaction (5)).

[6] Although the loss of $\mathrm{O}\left({ }^{3} \mathrm{P}\right)$ has been observed in the reaction of trans-1,2-dichloroethene with ozone [Niki et al.,

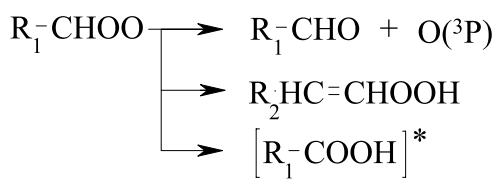

1983], in the ozonolysis of simple alkenes $\mathrm{O}\left({ }^{3} \mathrm{P}\right)$ atoms are not formed in significant amounts. The oxygen atom channel is energetically accessible, but cannot compete with the other pathways [Anglada et al., 1996]. Stabilized Criegee intermediates may persist long enough in the atmosphere to cause bimolecular reactions (e.g., reactions (8), (6), (7)).

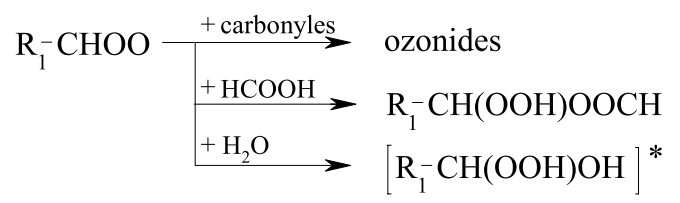

[7] The reaction with water (8) is of major importance in the atmosphere because of the high water concentration in the atmosphere. The reaction proceeds via an excited $\alpha$-hydroxy hydroperoxide which can decompose to form an aldehyde and hydrogen peroxide (10), a carboxylic acid (11) or $\mathrm{OH}$ radicals (9) [Anglada et al., 2002; Aplincourt and Anglada, 2003; Baker et al., 2001; Neeb et al., 1997; Ryzhkov and Ariya, 2004]. The influence of humidity on the $\mathrm{OH}$ yield of alkene ozonolysis is still a matter of debate. Although quantum mechanical calculations indicate that humidity increases $\mathrm{OH}$ production [Anglada et al., 2002], in four studies no influence of humidity on $\mathrm{OH}$ production in ozonolysis was observed [Aschmann et al., 2002; Atkinson and Aschmann, 1993; Atkinson et al., 1992; Hasson et al., 2003].

$$
\begin{aligned}
{\left[\mathrm{R}_{1}^{-} \mathrm{CH}(\mathrm{OOH}) \mathrm{OH}\right]^{*} } & >\mathrm{R}_{1}^{-} \mathrm{CH}(\mathrm{O}) \mathrm{OH}+\mathrm{OH} \\
& >\mathrm{R}_{1}^{-} \mathrm{CHO}+\mathrm{H}_{2} \mathrm{O}_{2} \\
& >\mathrm{R}_{1}^{-} \mathrm{COOH}+\mathrm{H}_{2} \mathrm{O}
\end{aligned}
$$

[8] Stabilized Criegee intermediates which do not react in bimolecular reactions are believed to decompose via the pathways (4) or (5) [Kroll et al., 2001; Olzmann et al., 1997]. The importance of the hydroperoxide channel (4) and the ester channel (5) depends on the substituents and the stereochemistry of the Criegee intermediate. The stereochemistry of the parent alkene determines whether unsymmetrically substituted Criegee intermediates are formed as the $s y n$-isomer or the anti-isomer. The interconversion of these stereoisomers is prevented by a high rotational barrier [Cremer, 1979]. Criegee intermediates possessing a hydrogen atom at an alkyl residue in the syn position are prone to undergo isomerization via a five-membered transition state to form a vinyl hydroperoxide (reaction (4)). This unstable compound may decompose to a ketene (12) or a ketoaldehyde (13). Another possibility is the formation of an $\mathrm{OH}$ radical and an acyl radical (14). Recent calculations [Kuwata et al., 2003] showed that acyl radicals formed in this reaction may also contribute to the overall $\mathrm{OH}$ production after the addition of oxygen. Finally, the hydroxyperoxide may form a hydroxy aldehyde (15) or decompose to acyl radicals (16) which immediately react with oxygen to produce hydroperoxy radicals, aldehydes (17), and carbon monoxide (18) [Mihelcic et al., 1999].

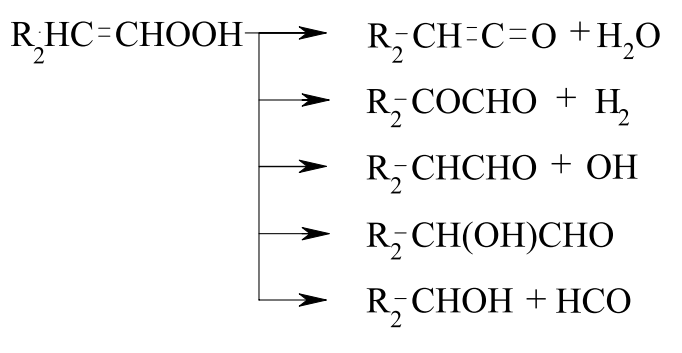

$$
\begin{array}{r}
\mathrm{R}_{2}^{-} \mathrm{CHOH}+\mathrm{O}_{2} \rightarrow \mathrm{HO}_{2}+\mathrm{R}_{2}^{-} \mathrm{CHO} \\
\mathrm{HCO}+\mathrm{O}_{2} \rightarrow \mathrm{HO}_{2}+\mathrm{CO}
\end{array}
$$

[9] The anti-Criegee intermediate is believed to react via the ester channel where it forms a dioxirane (19) which reacts to a vibrationally excited acid (20). Criegee intermediates with two alkyl substituents do not react to the corresponding ester, because an alkyl group has to be transferred instead of a hydrogen atom. For these compounds the hydroperoxide channel (4) is favored [Olzmann et al., 1997]. 


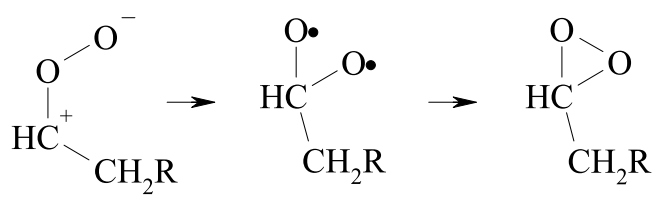

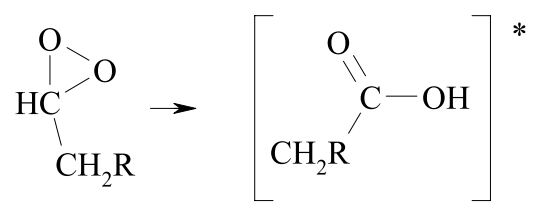

[10] Decomposition of the acid may result in alkanes (21), ketenes (24), hydroxyl, and acyl radicals (22). Although this reaction channel may contribute substantially to the overall $\mathrm{OH}$ production [Kroll et al., 2002], it is believed that $\mathrm{OH}$ production via the hydroperoxide channel is more effective when this reaction channel is accessible. The cleavage of the acid in reaction (25) results in alkyl und hydrogen radicals. Both will react immediately with oxygen to peroxy (26) and hydroperoxy radicals (27).

$$
\begin{aligned}
{\left[\mathrm{R}_{1}^{-} \mathrm{COOH}\right]^{*}[} & \mathrm{R}_{1}^{-} \mathrm{H}+\mathrm{CO}_{2} \\
& \rightarrow \mathrm{R}_{1}^{-} \mathrm{CO}+\mathrm{OH} \\
& \rightarrow \mathrm{R}_{1}^{-} \mathrm{COOH} \\
& \rightarrow \mathrm{R}_{2}^{-} \mathrm{CH}=\mathrm{C}=\mathrm{O}+\mathrm{H}_{2} \mathrm{O} \\
& \mathrm{R}_{1}+\mathrm{CO}_{2}+\mathrm{H} \\
\mathrm{R}_{1}+\mathrm{O}_{2} & \rightarrow \mathrm{R}_{1}^{-} \mathrm{O}_{2} \\
\mathrm{H}+\mathrm{O}_{2} & \rightarrow \mathrm{HO}_{2}
\end{aligned}
$$

[11] Additionally, it was suggested that $\mathrm{OH}$ radicals may be formed in stepwise degradation of the primary ozonide (28). The ozonide cleavage is thought to be a concerted process but could also proceed via a biradical [Chan and Hamilton, 2003], which could react to an excited hydroperoxide that is cleaved to release OH (29) [Anglada et al., 1999; Fenske et al., 2000].

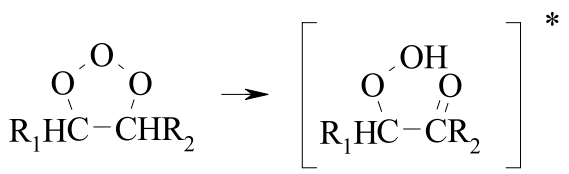

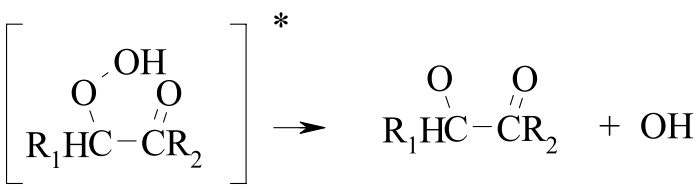

[12] However, although $\mathrm{OH}$ production from ozonolysis has been observed both directly [Kroll et al., 2002; Mihelcic et al., 1999] and indirectly [Neeb and Moortgat, 1999], the $\mathrm{OH}$ yields from particular ozonolysis reactions remain uncertain, as the influence of humidity on $\mathrm{OH}$ yields does.

[13] Ab initio calculations [Anglada et al., 2002] indicate that water can form complexes with carbonyl oxides and act either as reactant or as catalyst. When water adds to the carbonyl oxide a hydroxy hydroperoxide is formed (30) which can decompose (31) to yield $\mathrm{OH}$ radicals or aldehydes.
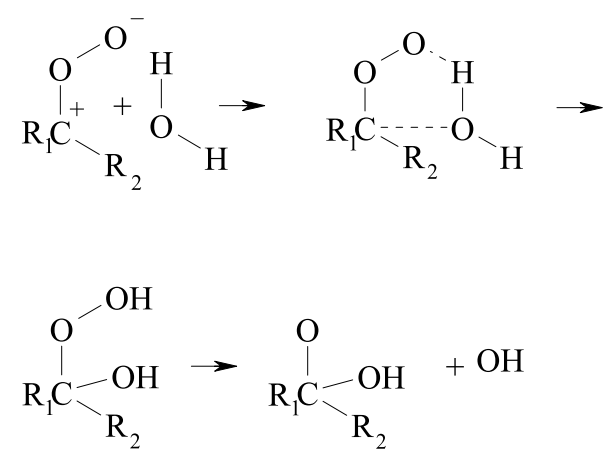

[14] Humidity also accelerates the formation of vinyl hydroperoxides via the hydroperoxide channel [Anglada et al., 2002] $(32,33)$.<smiles></smiles><smiles>[R]OOO</smiles>

[15] For unsymmetrical carbonyl oxides the product yield is determined by the configuration of the molecule. According to ab initio studies [Anglada et al., 2002], anti$\mathrm{CH}_{3} \mathrm{HCOO}\left(30, \mathrm{R}_{1}=\mathrm{CH}_{3}, \mathrm{R}_{2}=\mathrm{H}\right)$ reacts under humid conditions to form a hydroxy hydroperoxide via the stabilized channel (30). While syn- $\mathrm{CH}_{3} \mathrm{HCOO}\left(32, \mathrm{R}_{1}=\mathrm{H}\right)$ can react either to an $\alpha$-hydroxy hydroperoxide (31) or to the vinyl hydroperoxide via the hydroperoxide channel (33). The ester channel was ruled out by the authors owing to its high activation energy. Although these quantum mechanical calculations indicate that humidity increases $\mathrm{OH}$ production [Anglada et al., 2002], in five studies no influence of humidity on $\mathrm{OH}$ production in ozonolysis was observed [Aschmann et al., 2002; Atkinson and Aschmann, 1993; Atkinson et al., 1992; Hasson et al., 2003; Johnson et al., 2001].

[16] In previous studies $\mathrm{OH}$ yields were determined directly by monitoring $\mathrm{OH}$ either by laser-induced fluorescence (LIF) [Kroll et al., 2001; Siese et al., 2001] or after 


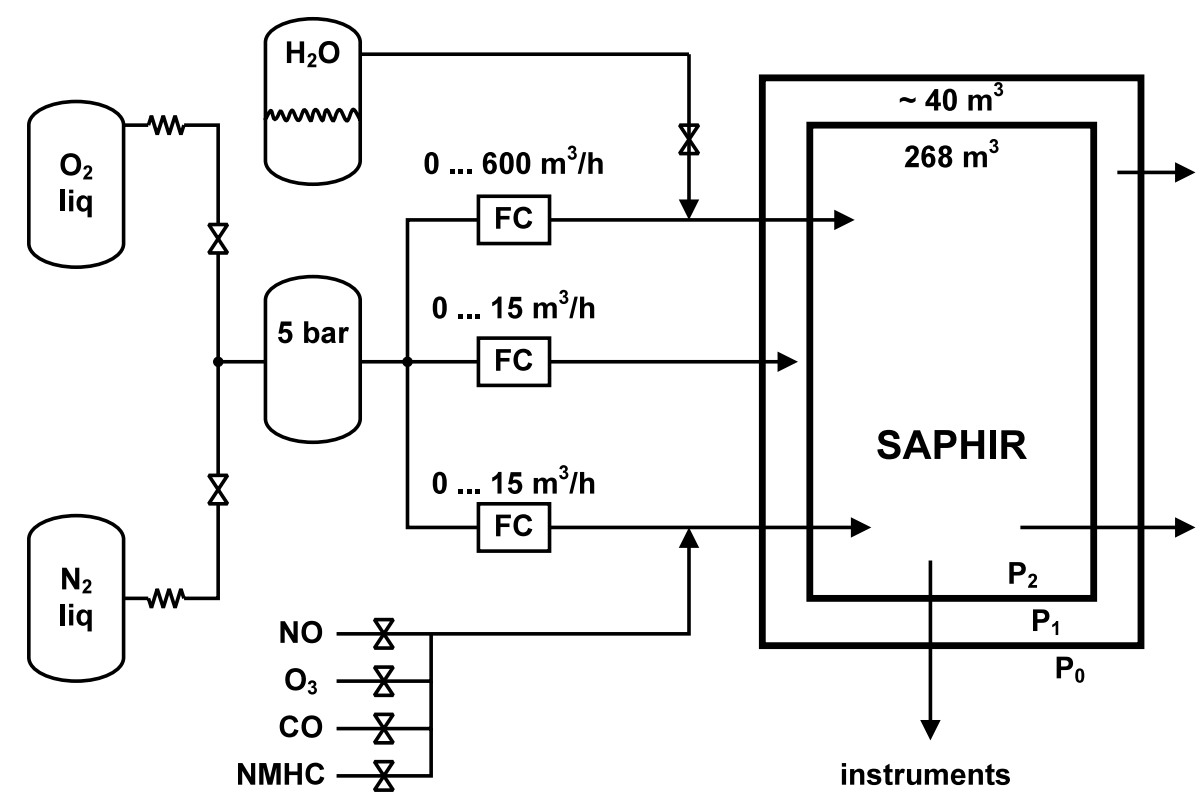

Figure 1. Simplified flowchart of the atmosphere simulation chamber SAPHIR. For details, see text.

conversion to $\mathrm{HO}_{2}$ by matrix isolation and electron spin resonance spectroscopy (MIESR) [Mihelcic et al., 1999]. In other studies $\mathrm{OH}$ radicals are scavenged by components, whose turnover is observed to deduce the $\mathrm{OH}$ yields. The formation yield of cyclohexanol and cyclohexanone from cyclohexane [Atkinson and Aschmann, 1993], butanone from 2-butanol [Chew and Atkinson, 1996; Aschmann et al., 2002], and $\mathrm{CO}_{2}$ from $\mathrm{CO}$ [Gutbrod et al., 1997] was observed to monitor $\mathrm{OH}$ production. When fast reacting tracers like trimethylbenzene [Paulson et al., 1999; Rickard et al., 1999] are used, OH yields can be deduced from the diminution in concentration of these species. A different approach is to monitor the difference in the turnover of the alkene compared to ozone [Horie et al., 1994]. Unlike ozone, alkenes react with $\mathrm{OH}$. The additional alkene consumption reflects the $\mathrm{OH}$ yield of ozonolysis.

[17] In ozonolysis of 1-alkenes formaldehyde can be formed either as primary carbonyl (reaction (2)) or from the Criegee intermediate. Formaldehyde generation via the Criegee intermediate proceeds after addition of water (reaction (10), $\mathrm{R}_{1}=\mathrm{H}$ ) or via the hydroperoxide ((17), $\left.\mathrm{R}_{2}=\mathrm{H}\right)$ [Atkinson, 1997].

[18] Since aldehydes are formed both as primary carbonyl and from Criegee intermediates, the carbonyl yield can exceed 1 [Atkinson, 1997]. The additional formaldehyde formation from dimethyl carbonyl oxides was accounted by an additional pathway via the hydroperoxide (reactions (34), (35), (36), and (37)) [Tuazon et al., 1997].

$$
\begin{gathered}
\mathrm{H}_{2} \mathrm{C}=\mathrm{C}\left(\mathrm{CH}_{3}\right) \mathrm{OOH} \rightarrow \mathrm{CH}_{2}(\mathrm{CO}) \mathrm{CH}_{3}+\mathrm{OH} \\
\mathrm{CH}_{2}(\mathrm{CO}) \mathrm{CH}_{3}+\mathrm{O}_{2} \rightarrow \mathrm{CH}_{3}(\mathrm{CO}) \mathrm{CH}_{2} \mathrm{O}_{2} \\
\mathrm{CH}_{3}(\mathrm{CO}) \mathrm{CH}_{2} \mathrm{O}_{2}+\mathrm{RO}_{2} \rightarrow \mathrm{CH}_{3}(\mathrm{CO}) \mathrm{CH}_{2} \mathrm{O}+\mathrm{RO}+\mathrm{O}_{2} \\
\mathrm{CH}_{3}(\mathrm{CO}) \mathrm{CH}_{2} \mathrm{O} \rightarrow \mathrm{CH}_{3} \mathrm{CO}+\mathrm{H}_{2} \mathrm{CO}
\end{gathered}
$$

[19] The aim of the present study was to determine the reaction rate coefficient $\left(k_{O_{3}}\right.$ in (38)) of the ozonolysis of 6 short-length alkenes in the atmosphere simulation chamber Simulation of Atmospheric Photochemistry in a Large Reaction Chamber (SAPHIR).

[20] The yields of $\mathrm{OH}$ ( $\alpha$ in reaction scheme 38) and $\mathrm{HO}_{2}$ ( $\beta$ in reaction 38) were determined in an indirect way by observing the turnover of the alkenes and ozone compared to experiments where radicals were scavenged. The yields of the stable products formaldehyde ( $\delta$ in (38)), acetaldehyde ( $\varepsilon$ in (38)), and $\mathrm{CO}(\phi$ in (38)) were determined by measuring the concentration time profiles of the respective species.

$$
\begin{gathered}
\text { alkene }+\mathrm{O}_{3} \stackrel{k o_{3}}{\longrightarrow} \begin{array}{l}
\alpha \mathrm{OH}+\beta \mathrm{HO}_{2}+\gamma \mathrm{R}_{1}-\mathrm{O}_{2}+\delta \mathrm{HCHO} \\
+\varepsilon \mathrm{CH}_{3} \mathrm{CHO}+\phi \mathrm{CO}+\text { products }
\end{array} \\
\text { alkene }+\mathrm{OH} \rightarrow \mathrm{R}_{2}-\mathrm{O}_{2}
\end{gathered}
$$

\section{Experimental Section}

\subsection{Atmosphere Simulation Chamber SAPHIR}

[21] The atmosphere simulation chamber SAPHIR (Figure 1) [Rodriguez Bares, 2003; Rohrer et al., 2005] consists of an almost cylindrical, double-wall Teflon tube held in a steel frame. The inner tube $(\mathrm{r}=2.5 \mathrm{~m}, \mathrm{~L}=18.4 \mathrm{~m})$ is used as a reactor for simulation experiments. The volume of the reactor is $268 \pm 25 \mathrm{~m}^{3}$. With an inner surface area of $324 \mathrm{~m}^{2}$ the volume/surface ratio of the reactor is about $0.8 \mathrm{~m}$. The space between the inner and outer tube is $\sim 0.1 \mathrm{~m}$. The space is continuously flushed with synthetic air of high purity to prevent permeation of trace gases from outside into the reactor. The inner tube consists of FEP film with a thickness of $125 \mu \mathrm{m}$ except for the ground $\left(52 \mathrm{~m}^{2}\right)$ made of $500 \mu \mathrm{m}$ FEP film. The outer tube consists of $250 \mu \mathrm{m}$ FEP film. Complete mixing of the chamber air is obtained within 
$\sim 1 \mathrm{~h}$ in the dark chamber. The loss of air through instruments and small leaks is about $3-4 \mathrm{~m}^{3} \mathrm{~h}^{-1}$ which is compensated by adding pure synthetic air freshly mixed from high-purity gases $\left(\mathrm{N}_{2}: \mathrm{O}_{2}=79: 21\right.$, purity $99.99999 \%$ for both $\mathrm{N}_{2}$ and $\mathrm{O}_{2}$ ) through a separate inlet line into the chamber (replenishment flow) to keep the pressure inside the chamber almost constant. This leads to a dilution of all trace gases in the chamber, which has to be considered for any interpretation of the chemical processes studied in the chamber. Minimum humidity at a dew point of $-50^{\circ} \mathrm{C}$ or 0.08 mbar of water can be reached when the chamber is flushed more then ten times its volume.

[22] The SAPHIR chamber is equipped with a comprehensive set of instruments including the measurements of concentrations of radicals, carbon monoxide, volatile organic compounds, nitrogen oxides and ozone. Physical parameters such as temperature, pressure, and humidity are also routinely monitored. In case the chamber is used for the investigations of photochemical processes, photolysis frequencies of atmospheric key processes are measured, too.

\subsection{Instrumentation}

[23] All analytical instruments are installed in laboratory containers which have access to the chamber via a special flange system that holds the inlet lines or allows installation of instruments into the chamber. Air samples are taken using stainless steel inlet lines covered outside with FEP about $1 \mathrm{~m}$ above the chamber floor to make sure that the samples are representative for the whole chamber and to avoid any influence of "local" processes near to the walls of the chamber.

[24] Supply of air samples for GC measurements from the chamber is done using a stainless steel sampling line ( $8 \mathrm{~mm} \mathrm{ID,} \mathrm{L} \sim 20 \mathrm{~m}$ ). Air is sucked out of the chamber by a metal bellows pump at a flow rate of $6 \mathrm{~L} \mathrm{~min}^{-1}$. The pressure in this part of the inlet line is about $50 \mathrm{hPa}$ below ambient pressure and the residence time in the line is $<10 \mathrm{~s}$. From the outlet of the metal bellows pump the air is fed into a second stainless steel line at a pressure of about $50 \mathrm{hPa}$ above ambient pressure. This line is used to flush the sampling loops of the gas chromatograph for the $\mathrm{CO}$ measurement.

\subsubsection{Nonmethane Hydrocarbons}

[25] Nonmethane hydrocarbons (NMHC) are quantified with a gas chromatograph (Chrompack VOCAir, Chrompack, the Netherlands) equipped with a flame ionization detector and a cryo focus module (Auto-TCT, Chrompack, the Netherlands). Sampling for NMHC analysis is done from the low-pressure side of the inlet line at $30 \mathrm{~mL} \mathrm{~min}^{-1}$. Before preconcentration water vapor is removed using a cold trap (SilcoSteel tube, $\mathrm{L}=600 \mathrm{~mm}$, ID $=4 \mathrm{~mm}$ ) at $233 \mathrm{~K}$. After removing the water the NMHC are sampled at $253 \mathrm{~K}$ on an adsorption tube (glass tube, $\mathrm{L}=16 \mathrm{~cm}$, ID = $2 \mathrm{~mm}$ ) packed with Carbotrap C, Carbotrap, and Carbosieve SIII. Since $\mathrm{CO}_{2}$ is also partly trapped on the preconcentration tube, the tube is heated to $293 \mathrm{~K}$ after preconcentration and purged backward with ultrapure $\mathrm{He}(99.9999 \%$ purity) at $100 \mathrm{~mL} \mathrm{~min}{ }^{-1}$ to remove the $\mathrm{CO}_{2}$ from the sample. The NMHC are then thermally desorbed at $523 \mathrm{~K}$ and transferred to a capillary column (PoraPlot $\mathrm{U}, \mathrm{L}=300 \mathrm{~mm}, \mathrm{ID}=0.53 \mathrm{~mm}$, film thickness $=20 \mu \mathrm{m}$ ) were they are cryofocused at $113 \mathrm{~K}$ to reduce peak width. After the cryofocusing step the capillary column is heated to $413 \mathrm{~K}$ and the NMHC are transferred to the gas chromatograph. Peak separation is performed on a fused silica column $\left(\mathrm{Al}_{2} \mathrm{O}_{3}, \mathrm{KCl}\right.$ deactivated, $\mathrm{L}=25 \mathrm{~m}, \mathrm{ID}=$ $0.32 \mathrm{~mm}$, film thickness $=5 \mu \mathrm{m})$. The initial temperature of the GC oven is held at $328 \mathrm{~K}$ for $2.5 \mathrm{~min}$, then ramped at $10 \mathrm{~K} \mathrm{~min}^{-1}$ to $398 \mathrm{~K}$, and then at $15 \mathrm{~K} \mathrm{~min}^{-1}$ to $473 \mathrm{~K}$ followed by an isothermal phase of $25 \mathrm{~min}$. Helium is used as carrier gas at a flow rate of $5 \mathrm{~mL} \mathrm{~min}{ }^{-1}$.

[26] Calibration is done using a commercially available certified 30 compound standard mixture of NMHC in synthetic air (NPL, UK). NMHC mixing ratios in this standard mixture range from 2 to $7 \mathrm{ppbV}$. The variation of the individual mass response factors is less than $8 \%$. The detection limit for most of the compounds is less than $10 \mathrm{pptV}$.

\subsubsection{Carbon Monoxide}

[27] The mixing ratios of carbon monoxide are analyzed with a reduction gas analyzer (RGA-3, Trace Analytical, USA). The air sample is injected from a $1 \mathrm{~mL}$ sample loop onto a packed column (ID $=2 \mathrm{~mm}, \mathrm{~L}=800 \mathrm{~mm}$, molecular sieve 5A) and is separated isothermally at $378 \mathrm{~K}$. Detection is done using heated mercury oxide (@ $\mathrm{T}=538 \mathrm{~K}$ )which is reduced to mercury vapor by gases like carbon monoxide, hydrogen and light NHMC. The concentration of mercury vapor is measured by UV absorption spectrometry. The time resolution of the measurements is $3 \mathrm{~min}$.

[28] The calibration curve (third-order polynomial) of the system is regularly checked between the detection limit of $5 \mathrm{ppbV}$ and $600 \mathrm{ppbV}$ using commercially available certified standard mixtures (Linde, Germany). The reproducibility is better than $4 \%$, the accuracy better than $10 \%$.

\subsubsection{Formaldehyde}

[29] Formaldehyde is measured by use of a commercially available but modified instrument (AL4001, AERO Laser $\mathrm{GmbH}$, Garmisch-Partenkirchen, Germany) based on the Hantzsch reaction [Kelly and Fortune, 1994; Nash, 1953]. The air sample is drawn through a stainless steel stripping coil at $285 \mathrm{~K}$ with a sampling flow rate of $1 \mathrm{~L} \mathrm{~min}^{-1}$ (STP) and a stripping solution flow rate of $\sim 0.4 \mathrm{~mL} \mathrm{~min}^{-1}$. The liquid flow rate is continuously measured [Krinke, 1999]. The gas phase formaldehyde is stripped out with a $0.05 \mathrm{~mol} \mathrm{~L}^{-1} \mathrm{H}_{2} \mathrm{SO}_{4}$ solution and derivatized using a solution of acetyl acetone, ammonium acetate and acetic acid at $\sim 343 \mathrm{~K}$ to yield the fluorescence compound 3,5diacetyl-1,4-dihydrolutidine. The accuracy of the instrument is better than $5 \%(3 \sigma)$ at $\mathrm{HCHO}$ mixing ratios of $10 \mathrm{ppb}$. The limit of detection is below 40 ppt calculated from the noise of the zero signal. The response time of the device has been determined to be $\sim 3 \mathrm{~min}$. A potential interference of ozone to the formaldehyde measurements was ruled out by injecting ozone to the SAPHIR chamber in the absence of alkenes and formaldehyde. The instrument is calibrated before and after a set of experiments by means of liquid standards prepared from a formaldehyde stock solution whose concentration is repeatedly checked.

\subsubsection{Acetaldehyde}

[30] Acetaldehyde is measured by proton transfer reaction mass spectrometry (PTR-MS), a technique which uses proton transfer reactions with $\mathrm{H}_{3} \mathrm{O}^{+}$ions for real-time measurements of organic trace gases. The PTR-MS technique is described in detail by [Lindinger et al., 1998]. For the experiments presented here, chamber air was sampled at a flow rate of $2.1 \mathrm{~L} \mathrm{~min}^{-1}(\mathrm{STP})$ through a Teflon line $(\mathrm{L}=$ $5 \mathrm{~m}$; OD $=0.32 \mathrm{~cm})$. The instrument was calibrated using capillary diffusion sources [Komenda et al., 2003]; the 
instrumental background is determined by periodically diverting the sample flow through an organic trace gas scrubber (platinum-coated quartz wool, $\mathrm{T}=623 \mathrm{~K}$ ). The detection limit of the system for $\mathrm{CH}_{3} \mathrm{CHO}$ is $50 \mathrm{pptV}$ and the estimated accuracy is $\pm 20 \%$. For the studied ozonolysis reactions there is currently no evidence indicating the presence of any interfering species at $\mathrm{m} / \mathrm{e}=45$ (protonated acetaldehyde). Also, acetaldehyde artifacts due to heterogeneous ozone reactions in the chamber were found to be negligible. However, strictly speaking, all reported acetaldehyde yields have to be considered as upper limits.

\subsubsection{Ozone}

[31] $\mathrm{O}_{3}$ is monitored via UV absorption (Ansyco O341M) with a detection limit of $1 \mathrm{ppb}$ and a precision of $0.5 \mathrm{ppb}$ at $90 \mathrm{~s}$ time resolution.

\subsubsection{Water}

[32] Humidity was determined with a frost point hygrometer (General Eastern model Hygro M4).

\subsection{Injection of Trace Gases}

\subsubsection{Ozone}

[33] Ozone is generated by an ozonizator (Ozat CFS-1A, Ozonia, Switzerland) which generates ozone in a silent discharge in high-purity $\mathrm{O}_{2}$. This prevents the formation of radicals, aldehydes or other unwanted compounds during the process of ozone generation. To reach an ozone mixing ratio in the chamber of about $30 \mathrm{ppb}$, ozone has to be generated for about $15 \mathrm{~s}$.

\subsubsection{Water Vapor}

[34] Water vapor for the injection into the chamber is produced from ultrapure water (Milli-Q, Millipore) which is stored in a special reservoir vessel. $\mathrm{N}_{2}$ of high purity $(99.99999 \%)$ is continuously bubbled trough the water in this vessel in order to remove any dissolved trace gases. The trace gas free water is then vaporized using a vaporizer (Dampf-O-Mat) and injected into the SAPHIR chamber via the purge gas flow at a high flow rate.

\subsubsection{Other Trace Gases}

[35] All other trace gases are injected into the chamber via the replenishment flow. CO (Messer Griesheim, Germany, purity $99.997 \%$ ) is directly injected from a high-pressure cylinder via a mass flow controller. The mixing ratio in the chamber is adjusted by the flow rate and the duration of injection. Alkenes are injected from a stainless steel injection loop of known volume at an appropriate pressure to ensure the proposed mixing ratios in the chamber. The alkenes were purchased from Linde AG, Germany, with purities of $99.95 \%$ for ethene, propene, and isobutene, and $99 \%$ for the other alkenes.

\subsection{Ozonolysis Experiments}

[36] Before experiments were started the chamber volume was flushed with synthetic air freshly mixed from highpurity gases $\left(\mathrm{N}_{2}: \mathrm{O}_{2}=79: 21\right.$, purity $99.99999 \%$ for both $\mathrm{N}_{2}$ and $\mathrm{O}_{2}$ ) at $300 \mathrm{~m}^{3} \mathrm{~h}^{-1}$ for several hours to purge all trace gases below the detection limits of the instruments. After flushing the chamber, the compounds of interest were injected. The order of introduction of the reactants ozone and the alkenes was not fixed, but carbon monoxide was added prior to the introduction of the second reactant to scavenge $\mathrm{OH}$ radicals formed.
[37] Several experiments were conducted with each alkene (Table 1). Ozonolysis was studied both under humid (2000-10000 ppm water) and dry ( 100 ppm water) conditions to evaluate the influence of humidity on ozonolysis. To minimize the error in $\mathrm{OH}$ yield determination experiments were conducted under conditions where $\mathrm{OH}$ is almost exclusively produced by alkene ozonolysis and consumed by reaction with the alkene. Experiments were conducted in a $\mathrm{NO}_{\mathrm{x}}$-free atmosphere in the dark chamber to avoid additional $\mathrm{OH}$ production by recycling of $\mathrm{OH}$ from $\mathrm{HO}_{2}$ by $\mathrm{NO}_{\mathrm{x}}$ or $\mathrm{OH}$ production by photolysis. The $\mathrm{NO}_{\mathrm{x}}$ mixing ratio was monitored during the experiments. Since the $\mathrm{NO}_{\mathrm{x}}$ mixing ratio was always below $100 \mathrm{pptV}$ and several $\mathrm{ppb} \mathrm{O}_{3}$ were added into the chamber, formation of $\mathrm{OH}$ from reduction of $\mathrm{HO}_{2}$ by $\mathrm{NO}$ was negligible. Likewise, the reaction of $\mathrm{NO}_{3}$ with alkenes can be neglected.

[38] Reaction rate coefficients $\left(k_{\mathrm{O}_{3}}\right)$ and product yields $(\alpha$, $\beta, \delta, \varepsilon, \phi)$ were calculated by comparing the measurements with model calculations. The parameters to be determined were varied in the model and the deviation between experimental $[X]_{i}^{\exp }$ and numerically modeled $[X]_{i}^{\text {model }}$ data evaluated using the method of minimizing $\chi^{2}$ calculated from the deviation of model and experiment data and from the standard deviation of the measurement $\sigma(X)$. For comparison, $\chi^{2}$ was standardized by dividing it by the number of data points.

$$
\chi^{2}(X)=\sum_{i}\left(\frac{[X]_{i}^{\exp }-[X]_{i}^{\text {model }}}{\sigma(X)}\right)^{2}
$$

[39] The agreement between the numerical model and the measured data is best when $\chi^{2}$ is minimal with respect to the parameter varied. In cases when two parameters could not be determined independently (e.g., $\mathrm{OH}$ yield $\alpha$ and $\mathrm{HO}_{2}$ yield $\beta$ ), both parameters were varied and $\chi^{2}$ calculations were conducted with each combination of parameters.

[40] For determination of reaction rate coefficients $\mathrm{CO}$ was added in excess to scavenge $\mathrm{OH}$ and suppress side reactions. The reaction rate coefficients $k_{\mathrm{O}_{3}}$ recommended in the literature [Atkinson and Arey, 2003] were chosen as starting values for $\chi^{2}$ minimization and the scaling factor $F$ was varied from 0.6 to 1.4 with an increment of 0.05 . With each scaling factor $F$ a numerical simulation was conducted until deviation $\chi^{2}$ of observed mixing ratios and mixing ratios in numerical simulations was minimal. Since the SAPHIR chamber has no regular shape, its volume was determined experimentally by monitoring the dilution of an inert tracer. The uncertainty of the chamber volume is reflected by an uncertainty of the dilution rate $k_{d i l}(41)$.

$$
\frac{d[\text { alkene }]}{d t}=-\mathrm{F} k_{O_{3}}\left[O_{3}\right][\text { alkene }]-k_{\text {dil }}[\text { alkene }]
$$

[41] Both the chamber volume and the scaling factor were varied and $\chi^{2}$ was determined to evaluate the influence of this uncertainty on the estimation of reaction rate coefficients. For ethene ozonolysis which is slow compared to other alkenes, the uncertainty in the determination of the chamber volume contributes significantly to the uncertainty of the scaling factor $F$ for the reaction rate coefficient of \pm 0.1 and \pm 0.2 for the individual experiments. For the other alkenes the uncertainty of dilution can be neglected. 
Table 1. Initial Conditions, Temperature, and Duration of All Experiments ${ }^{\mathrm{a}}$

\begin{tabular}{|c|c|c|c|c|c|c|c|c|}
\hline & \multirow[b]{2}{*}{ Number } & \multirow[b]{2}{*}{ Type } & \multicolumn{4}{|c|}{ Initial Mixing Ratio } & \multirow[b]{2}{*}{$\begin{array}{c}\text { Duration, } \\
\mathrm{h}\end{array}$} & \multirow[b]{2}{*}{$\begin{array}{c}\text { Temperature, } \\
\mathrm{K}\end{array}$} \\
\hline & & & $\begin{array}{l}\text { Alkene, } \\
\text { ppbV }\end{array}$ & $\begin{array}{l}\text { Ozone, } \\
\text { ppbV }\end{array}$ & $\mathrm{CO}, \mathrm{ppmV}$ & $\begin{array}{c}\text { Water Vapor Partial } \\
\text { Pressure, mbar }\end{array}$ & & \\
\hline \multirow{4}{*}{ Ethene } & 1 & A & 172.0 & 167.0 & 0 & $\sim 0.1$ & 72 & $291 \pm 4$ \\
\hline & 2 & B & 173.5 & 179.0 & 0 & 8.98 & 72 & $290 \pm 3$ \\
\hline & 3 & $\mathrm{C}$ & 180.0 & 199.0 & 500 & $\sim 0.1$ & 36 & $293 \pm 2$ \\
\hline & 4 & D & 169.0 & 170.0 & 500 & 10.52 & 36 & $295 \pm 4$ \\
\hline \multirow[t]{6}{*}{ Propene } & 5 & A & 42.0 & 35.3 & 0 & $\sim 0.1$ & 10 & $287 \pm 3$ \\
\hline & 6 & A & 56.0 & 67.7 & 0 & $\sim 0.1$ & 10 & $289 \pm 1$ \\
\hline & 7 & B & 57.0 & 49.0 & 0 & 6.48 & 48 & $285 \pm 2$ \\
\hline & 8 & B & 61.5 & 76.0 & 0 & 8.74 & 9 & $295 \pm 1$ \\
\hline & 9 & $\mathrm{C}$ & 54.2 & 68.2 & 500 & $\sim 0.1$ & 12 & $295 \pm 2$ \\
\hline & 10 & D & 55.5 & 71.0 & 500 & 9.55 & 13 & $298 \pm 2$ \\
\hline \multirow[t]{4}{*}{ 1-Butene } & 11 & A & 53.3 & 52.5 & 0 & $\sim 0.1$ & 12 & $293 \pm 2$ \\
\hline & 12 & B & 56.0 & 64.7 & 0 & 9.24 & 12 & $294 \pm 2$ \\
\hline & 13 & $\mathrm{C}$ & 54.0 & 49.5 & 500 & $\sim 0.1$ & 12 & $294 \pm 2$ \\
\hline & 14 & D & 55.1 & 51.3 & 500 & 10.35 & 12 & $292 \pm 1$ \\
\hline \multirow[t]{4}{*}{ Isobutene } & 15 & A & 52.2 & 45.2 & 0 & $\sim 0.1$ & 12 & $295 \pm 1$ \\
\hline & 16 & B & 60.5 & 51.8 & 0 & 10.66 & 12 & $298 \pm 1$ \\
\hline & 17 & $\mathrm{C}$ & 50.0 & 54.3 & 500 & $\sim 0.1$ & 12 & $296 \pm 1$ \\
\hline & 18 & D & 55.2 & 60.0 & 500 & 10.66 & 12 & $297 \pm 2$ \\
\hline \multirow[t]{8}{*}{ (Z)-Butene } & 19 & A & 17.0 & 30.5 & 0 & $\sim 0.1$ & 24 & $291 \pm 4$ \\
\hline & 20 & A & 18.2 & 32.4 & 0 & $\sim 0.1$ & 6 & $296 \pm 2$ \\
\hline & 21 & B & 22.0 & 20.4 & 0 & 6.99 & 24 & $286 \pm 3$ \\
\hline & 22 & B & 20.0 & 34.0 & 0 & 1.30 & 24 & $290 \pm 3$ \\
\hline & 23 & B & 22.1 & 31.7 & 0 & 10.09 & 5 & $294 \pm 1$ \\
\hline & 24 & $\mathrm{C}$ & 20.5 & 15.2 & 500 & $\sim 0.1$ & 48 & $283 \pm 2$ \\
\hline & 25 & $\mathrm{C}$ & 19.2 & 23.0 & 500 & $\sim 0.1$ & 24 & $290 \pm 3$ \\
\hline & 26 & D & 22.0 & 22.0 & 500 & 2.22 & 48 & $282 \pm 2$ \\
\hline \multirow[t]{8}{*}{ (E)-Butene } & 27 & A & 21.3 & 21.5 & 0 & $\sim 0.1$ & 24 & $290 \pm 2$ \\
\hline & 28 & A & 34.0 & 31.0 & 0 & $\sim 0.1$ & 24 & $294 \pm 3$ \\
\hline & 29 & A & 21.4 & 26.8 & 0 & $\sim 0.1$ & 5 & $293 \pm 2$ \\
\hline & 30 & B & 20.8 & 31.5 & 0 & 8.93 & 24 & $293 \pm 3$ \\
\hline & 31 & B & 23.4 & 25.6 & 0 & 8.57 & 7 & $291 \pm 2$ \\
\hline & 32 & $\mathrm{C}$ & 22.2 & 20.5 & 500 & $\sim 0.1$ & 24 & $289 \pm 3$ \\
\hline & 33 & $\mathrm{C}$ & 20.8 & 32.5 & 500 & $\sim 0.1$ & 10 & $297 \pm 2$ \\
\hline & 34 & D & 24.3 & 27.0 & 500 & 13.92 & 8 & $295 \pm 2$ \\
\hline
\end{tabular}

${ }^{\mathrm{a}} \mathrm{A}$, without water; $\mathrm{B}$, with water only; $\mathrm{C}$, with $\mathrm{CO}$ only; and $\mathrm{D}$, with water and $\mathrm{CO}$.

The errors of the reaction rate coefficients depend on the increment of variation of the scaling factors $F$ in the numerical simulations which is 0.05 .

[42] $\mathrm{OH}$ yields were determined by monitoring the additional turnover of the alkene. To distinguish between alkene turnover by ozonolysis and by $\mathrm{OH}$ reaction, experiments were conducted with and without scavenging the radicals formed. In experiments when $\mathrm{OH}$ radicals are not scavenged by $\mathrm{CO}$, side reactions alter the turnover rate of the alkene and ozone (Figures $2 \mathrm{~b}$ and $2 \mathrm{c}$ ) compared to the turnover rates with radicals scavenged (Figure $2 \mathrm{a}$ ). Using the reaction rate coefficients obtained in the presence of carbon monox-
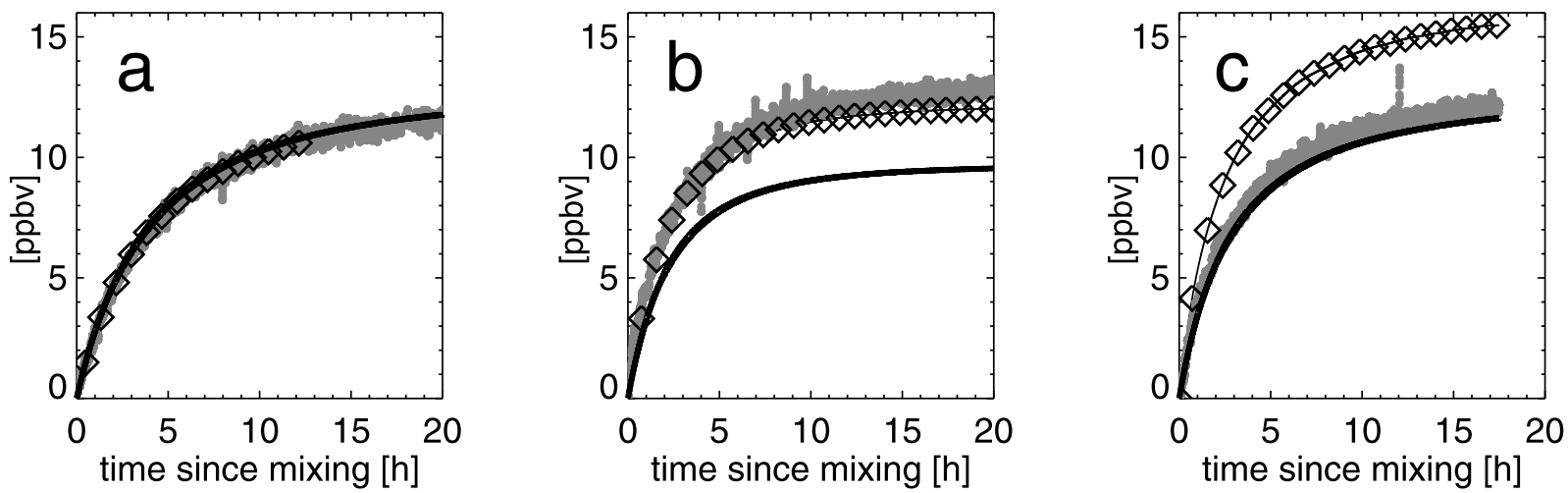

Figure 2. Accumulated turnover of ozone (gray dots) and ( $Z$ )-butene (diamonds) in different experiments conducted: (a) ozonolysis of (Z)-butene with $\mathrm{CO}$ as scavenger, experiment 26; (b) ozonolysis of $(Z)$-butene without $\mathrm{CO}$ in the dry chamber, experiment 19; and (c) ozonolysis of $(Z)$-butene without $\mathrm{CO}$ in the humid chamber, experiment 21 . The thick black line denotes turnover of the ozonolysis reaction calculated from the mixing ratio of the reactants ozone and $(Z)$-butene and the reaction rate coefficient observed in the experiment from Figure 2a. 
ide enabled the calculation of the portion of alkene reacting in side reactions with radicals formed during ozonolysis. Moreover, since alkenes react with $\mathrm{OH}$ (39) while ozone reacts with $\mathrm{HO}_{2}$ (42) reactions of $\mathrm{OH}$ and $\mathrm{HO}_{2}$ can be distinguished and both the $\mathrm{OH}$ yield ( $\alpha$ in reaction (38)) and the $\mathrm{HO}_{2}$ yield ( $\beta$ in reaction (38)) can be determined.

$$
\mathrm{HO}_{2}+\mathrm{O}_{3} \rightarrow \mathrm{OH}+2 \mathrm{O}_{2}
$$

[43] An increased $\mathrm{OH}$ production leads to an increased alkene turnover (Figure 2c). To minimize the error in $\mathrm{OH}$ yield determination, experiments were conducted under conditions where $\mathrm{OH}$ is almost exclusively produced by alkene ozonolysis and consumed by reaction with the alkene.

[44] Side reactions that consume $\mathrm{OH}$ radicals are reactions with aldehydes or ketones (43). When applied in numerical simulations uncertainties in the reaction rate coefficients of these reactions cause uncertainties in the $\mathrm{OH}$ yields. However, the errors in the reaction of the carbonyls with $\mathrm{OH}$ were corrected since carbonyls were measured in the experiments.

$$
\text { aldehydes } / \text { ketones }+\mathrm{OH} \rightarrow \text { products }
$$

[45] $\mathrm{HO}_{2}$ yields can be determined from the ozone turnover in reaction (42) analogue to the determination of $\mathrm{OH}$ yields. This reaction represents an additional $\mathrm{OH}$ source which may disturb accurate $\mathrm{OH}$ yield determination. Therefore it is not possible to optimize reaction conditions for an accurate determination of both $\mathrm{OH}$ and $\mathrm{HO}_{2}$ yields at the same time.

[46] Additional loss processes for $\mathrm{HO}_{2}$ are reactions with peroxy radicals (44a) and (44b) and $\mathrm{HO}_{2}$ self-reaction to form hydrogen peroxide (45). The yield of the latter reaction channel determines the recycling rate of $\mathrm{HO}_{2}$ to $\mathrm{OH}$. In addition to ozonolysis, $\mathrm{HO}_{2}$ radicals are produced from reaction with peroxy radicals in reactions (46a), (46b), and (46c). However, these reactions can be neglected since their turnover is small compared to the production of $\mathrm{HO}_{2}$ by ozonolysis.

$$
\begin{gathered}
\mathrm{HO}_{2}+\mathrm{R}_{1}^{-} \mathrm{O}_{2} \rightarrow \text { products } \\
\mathrm{HO}_{2}+\mathrm{R}_{2}^{-} \mathrm{O}_{2} \rightarrow \text { products } \\
\mathrm{HO}_{2}+\mathrm{HO}_{2} \rightarrow \mathrm{H}_{2} \mathrm{O}_{2}+\mathrm{O}_{2} \\
\mathrm{R}_{1}^{-} \mathrm{O}_{2}+\mathrm{R}_{1}^{-} \mathrm{O}_{2} \rightarrow \mathrm{HO}_{2}+\text { products } \\
\mathrm{R}_{2}^{-} \mathrm{O}_{2}+\mathrm{R}_{2}^{-} \mathrm{O}_{2} \rightarrow \mathrm{HO}_{2}+\text { products } \\
\mathrm{R}_{1}^{-} \mathrm{O}_{2}+\mathrm{R}_{2}^{-} \mathrm{O}_{2} \rightarrow \mathrm{HO}_{2}+\text { products }
\end{gathered}
$$

[47] Apart from the conditions required to minimize the error in $\mathrm{OH}$ yield determination as outlined above, exper- imental conditions were set to meet the following criteria: (1) The concentration of the reactants should be within the range of atmospheric conditions. (2) Alkene and ozone losses by reaction had to be larger than or at least equal to the loss by dilution to be monitored accurately. (3) The reaction products carbon monoxide, formaldehyde and acetaldehyde had to be detectable. The durations of experiments were set to ensure that enough data points were recorded. The limiting factor was the gas chromatography, with one measurement every with $50 \mathrm{~min}$.

[48] Numerical simulations of ozonolysis experiments were conducted using the Regional Atmospheric Chemistry Mechanism (RACM) [Stockwell et al., 1997]. The mechanism comprises a total of 237 reactions. The model includes the ozonolysis reactions (38), reactions with $\mathrm{OH}$ (39) as well as reactions (42)-(46). The model handles ethene explicitly. Propene, 1-butene, and isobutene are grouped and treated as terminal alkenes, the 2-butenes as internal alkenes. Radical yields and yields of long-living products as well as reaction rate coefficients of compound classes are weighted averages over all members of the respective class [Middleton et al., 1990]. Ketones, peroxy radicals, organic acids other than formic acid, and aldehydes larger than formaldehyde are also grouped into compound classes.

[49] Model calculations were conducted using FACSIMILE [Curtis and Sweetenham, 1987]. Measured temperature, chamber volume, experimental flow, humidity, and the mixing ratios of species measured were used as input values. To determine $\mathrm{HO}_{\mathrm{x}}$ yields the RACM model was adapted to include the reaction rate coefficients $k_{O_{3}}$ observed in the experiments with CO. To study an ozonolysis experiment of an individual alkene the model was adjusted by exchanging the average yields of the long-living products with the product yields of the respective alkene from the literature (Table 2) [Grosjean et al., 1996; Tuazon et al., 1997]. Reaction rate coefficients of the unspecified alkenes with $\mathrm{OH}$ (39) were replaced with the rate coefficients of the individual alkenes [Atkinson, 1997]. Reaction rate coefficients of unspecified aldehydes with $\mathrm{OH}$ (43) were exchanged with the reaction rate coefficients of the carbonyls produced (e.g., acetaldehyde for propene, $(E)$-butene, and $(Z)$-butene ozonolysis, propanal for 1-butene ozonolysis, and acetone for isobutene ozonolysis). Secondary peroxy radicals produced in reaction of alkenes with $\mathrm{OH}$ (39) were not specified. Hence, for reactions (44) and (46), the weighted means of reaction rate coefficients of all peroxy radicals produced in reaction (39) of that compound class were used.

[50] The $\mathrm{OH}$ yield $\alpha$ and the $\mathrm{HO}_{2}$ yield $\beta$ were acquired by varying both the yields in the numerical model and minimizing the total $\chi^{2}$. The expression $\chi^{2}$ (total) is the sum of $\chi^{2}$ for ozone and the alkene:

$$
\left.\left.\chi^{2}(\text { total })=\chi^{2} \text { (ozone }\right)+\chi^{2} \text { (alkene }\right)
$$

[51] Synchronization of ozone and alkene data with a time resolution of $5 \mathrm{~s}$ and $3000 \mathrm{~s}$, respectively, was conducted by interpolating the alkene data using cubic splines. The standard deviations of ozone and alkene were constant over the course of the experiment and were $0.25 \mathrm{ppb}$ and $0.13 \mathrm{ppb}$ respectively. Minimization of $\chi^{2}$ can be represented by contour plots where $\alpha$ and $\beta$ are 
Table 2. Ozonolysis Reaction in the Numerical Simulation (RACM) [Stockwell et al., 1997] Used to Calculate $\mathrm{OH}$ Yields $\alpha$ and $\mathrm{HO}_{2}$ Yields $\beta^{\text {a }}$

\begin{tabular}{lc}
\hline Alkene & Ozonolysis Reaction \\
\hline Ethene & ethene $+\mathrm{O}_{3} \rightarrow \alpha \mathrm{OH}+\beta \mathrm{HO}_{2}+\mathrm{HCHO}+0.43 \mathrm{CO}+0.37 \mathrm{ORA} 1+0.13 \mathrm{H}_{2}$ \\
Propene & propene $+\mathrm{O}_{3} \rightarrow \alpha \mathrm{OH}+\beta \mathrm{HO}_{2}+0.32 \mathrm{MO} 2+0.64 \mathrm{HCHO}+0.44 \mathrm{ALD}+0.37 \mathrm{CO}$ \\
& $+0.14 \mathrm{ORA} 1+0.10 \mathrm{ORA} 2+0.03 \mathrm{KET}+0.06 \mathrm{CH}_{4}+0.05 \mathrm{H}_{2}+0.006 \mathrm{H}_{2} \mathrm{O}_{2}$ \\
1-Butene & $1-$ butene $+\mathrm{O}_{3} \rightarrow \alpha \mathrm{OH}+\beta \mathrm{HO}_{2}+0.32 \mathrm{ETHP}+0.63 \mathrm{HCHO}+0.35 \mathrm{ALD}+0.37 \mathrm{CO}$ \\
& $+0.14 \mathrm{ORA} 1+0.10 \mathrm{ORA} 2+0.03 \mathrm{KET}+0.06 \mathrm{CH}_{4}+0.05 \mathrm{H}_{2}+0.006 \mathrm{H}_{2} \mathrm{O}_{2}+0.03 \mathrm{ETH}$ \\
Isobutene & isobutene $+\mathrm{O}_{3} \rightarrow \alpha \mathrm{OH}+\beta \mathrm{HO}_{2}+0.32 \mathrm{KETP}+0.74 \mathrm{HCHO}+0.37 \mathrm{CO}+0.14 \mathrm{ORA} 1$ \\
& $+0.10 \mathrm{ORA} 2+0.34 \mathrm{KET}+0.06 \mathrm{CH}_{4}+0.05 \mathrm{H}_{2}+0.006 \mathrm{H}_{2} \mathrm{O}_{2}+0.03 \mathrm{ETH}$ \\
$(Z)$-Butene & $(Z)$-butene $+\mathrm{O}_{3} \rightarrow \alpha \mathrm{OH}+\beta \mathrm{HO}_{2}+0.53 \mathrm{MO}+0.02 \mathrm{HCHO}+0.99 \mathrm{ALD}+0.16 \mathrm{KET}$ \\
& $+0.30 \mathrm{CO}+0.11 \mathrm{H}_{2} \mathrm{O}_{2}+0.14 \mathrm{ORA} 2+0.07 \mathrm{CH}_{4}$ \\
$(E)$-Butene & $(E)$-butene $+\mathrm{O}_{3} \rightarrow \alpha \mathrm{OH}+\beta \mathrm{HO} 2+0.53 \mathrm{MO} 2+0.02 \mathrm{HCHO}+0.99 \mathrm{ALD}+0.16 \mathrm{KET}$ \\
& $+0.30 \mathrm{CO}+0.11 \mathrm{H}_{2} \mathrm{O}_{2}+0.14 \mathrm{ORA} 2+0.07 \mathrm{CH}$ \\
\hline
\end{tabular}

\footnotetext{
${ }^{\mathrm{a}}$ To adapt the model for single alkenes the product yields were replaced by data for the individual alkenes [Grosjean et al., 1996; Tuazon et al., 1997]. Species are ORA1, formic acid; ORA2, acetic acids and higher acids; MO2, methyl peroxy radical; ALD, acetaldehyde and higher aldehydes; KET, ketones; KETP, peroxy radicals from ketones; ETHP, peroxy radicals from ethane; ETH, ethane.
}

plotted in $\mathrm{x}$ and $\mathrm{y}$ direction and points with equal $\chi^{2}$ are connected by isolines (Figures 3 and 4 ).

[52] Figure 3 shows contour plots of $\chi^{2}$ (total), $\chi^{2}$ (ozone), and $\chi^{2}$ (alkene) for an ozonolysis experiment of propene under dry conditions without a radical scavenger. In the plot for $\chi^{2}$ (alkene), $\alpha$ and $\beta$ are anticorrelated. A higher $\mathrm{OH}$ production rate $\alpha$ leads to a decrease in alkene concentration. This effect is balanced in the numerical model by increasing the $\mathrm{HO}_{2}$ yield and therefore decreasing the ozone concentration. In case of $\chi^{2}$ (ozone), $\alpha$ and $\beta$ are directly correlated. A larger $\mathrm{HO}_{2}$ yield $\beta$ causes a decrease in ozone mixing ratio by $\mathrm{HO}_{2}$ reaction, which is compensated in the numerical model by an increased $\mathrm{OH}$ production $\alpha$ leading to an additional alkene loss and therefore an increase in ozone concentration.

[53] The turnover of the reaction of ozone with $\mathrm{HO}_{2}$ was small, because reaction conditions were chosen in a way that $\mathrm{OH}$ is preferentially produced by ozonolysis and consumed by reaction with the alkenes. This is reflected in the contour plots for propene ozonolysis in Figure 3. The gradient in the $\chi^{2}$ plot for the alkene is higher than for ozone. The slope of the $\chi^{2}$ (total) plot will thus mainly be determined by the $\chi^{2}$ of the alkene.

[54] Also, the turnover rate of the reaction of ozone with $\mathrm{HO}_{2}$ is relatively small compared to the self-reaction of $\mathrm{HO}_{2}$ and the reaction of $\mathrm{HO}_{2}$ with peroxy radicals. Therefore the uncertainty for $\beta$ is much larger than for $\alpha$, which is reflected in the larger gradient for $\alpha$ than for $\beta$ in both the contour plots of alkene and ozone. This is even more obvious in the contour plots of $\left(E\right.$ )-butene (Figure 4), where recycling of $\mathrm{HO}_{2}$ by ozone is even less important than for propene. In this case, the isolines proceed almost vertical, indicating a large uncertainty in the determination of $\beta$. The uncertainties of $\beta$ in the ozonolysis of $(Z)$-butene and $(E)$-butene prevented the determination of $\mathrm{HO}_{2}$ yields of the 2-butenes.

[55] Experiments were set up that ozonolysis was the major $\mathrm{OH}$ source and reaction with alkenes the main $\mathrm{OH}$ sink. Systematic errors could derive from (1) additional $\mathrm{OH}$
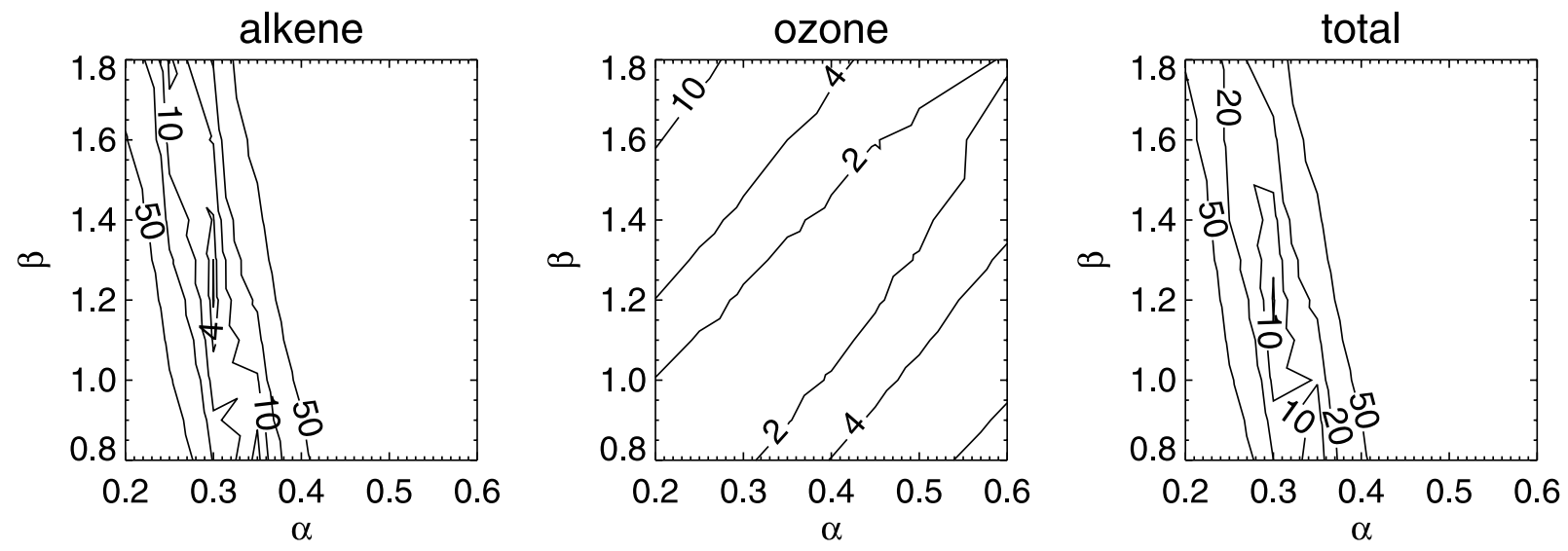

Figure 3. Deviation $\chi^{2}$ of experimental data from numerical simulations of propene ozonolysis under humid conditions with variable $\mathrm{OH}(\alpha)$ and $\mathrm{HO}_{2}$ yields $(\beta)$, experiment 8. Parameters $\alpha$ and $\beta$ were varied with an increment of 0.05 . For each combination of $\alpha$ and $\beta$, a numerical simulation was conducted. Solid lines represent equal $\chi^{2}$ values. Deviations $\chi^{2}$ are shown for single parameters alkene $\left(\chi^{2}\right.$ (alkene) $)$ and ozone $\left(\chi^{2}\right.$ (ozone) $)$ and for $\chi^{2}$ (total $=\chi^{2}$ (ozone) $+\chi^{2}$ (alkene)). Calculations were run with a peroxy radical yield $\gamma=0.32$. 

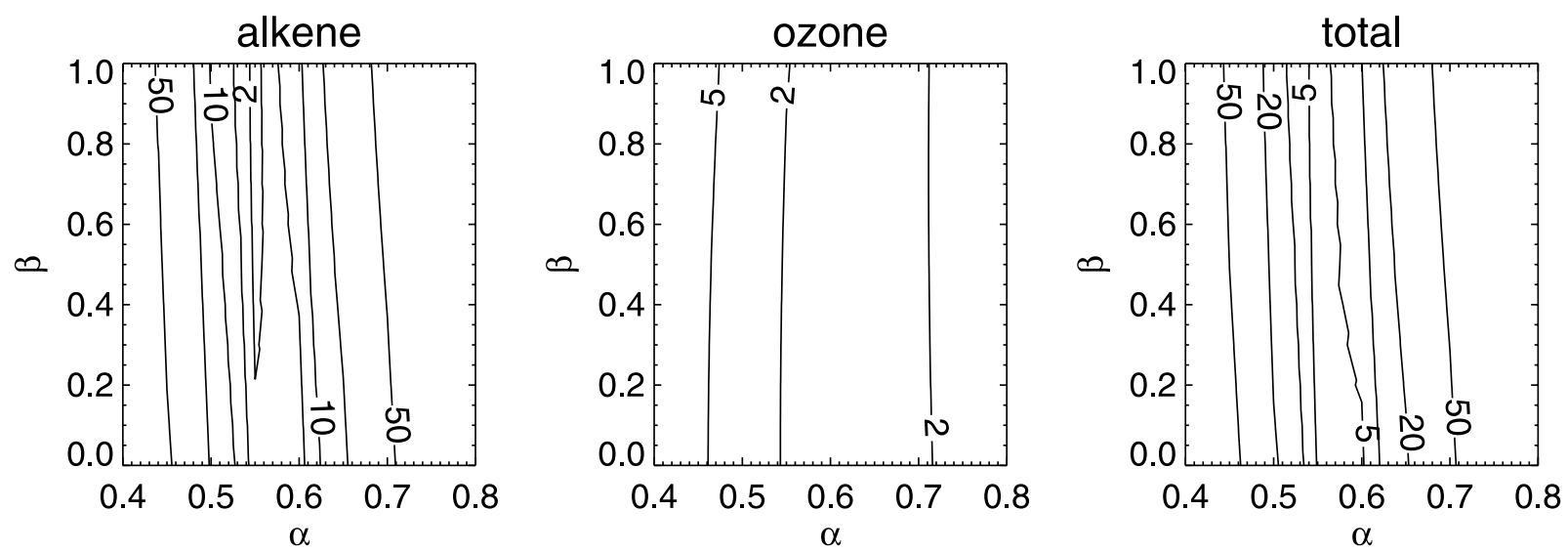

Figure 4. Deviation $\chi^{2}$ of experimental data from numerical simulations of $(E)$-butene ozonolysis under dry conditions with variable $\mathrm{OH}(\alpha)$ and $\mathrm{HO}_{2}$ yields $(\beta)$, experiment 27. Parameters $\alpha$ and $\beta$ were varied with an increment of 0.05 . For each combination of $\alpha$ and $\beta$, a numerical simulation was conducted. Solid lines represent equal $\chi^{2}$ values. Deviations $\chi^{2}$ are shown for single parameters alkene $\left(\chi^{2}\right.$ (alkene)) and ozone $\left(\chi^{2}\right.$ (ozone) $)$ and for $\chi^{2}$ (total $=\chi^{2}$ (ozone) $+\chi^{2}$ (alkene)).

formation by recycling of $\mathrm{OH}$ from $\mathrm{HO}_{2}$ and (2) additional $\mathrm{OH}$ loss by reaction with aldehydes and ketones. The uncertainty depends on the $\mathrm{HO}_{2}$ yields and can be significant at small $\alpha$ and large $\beta$ values.

$$
E_{\alpha}(\alpha, \beta)=E_{\mathrm{O}_{3}+\mathrm{HO}_{2}}+E_{\mathrm{OH}+\text { carbonyles }}
$$

[56] The total systematic error constitutes from (1) the error in the reaction rate coefficient of the reaction producing $\mathrm{OH}$ from $\mathrm{HO}_{2}$ and $\mathrm{O}_{3}$, (2) the error in the $\mathrm{HO}_{2}$ yields determined, and (3) the error in the reaction rate coefficients of the $\mathrm{OH}$ consuming reactions with carbonyls. The uncertainty for $\alpha$ was calculated from the total systematic error as outlined above, the absolute experimental error of 5\%, and from the standard deviation of repeated experiments. As can be seen from the contour plots in Figure 4 the uncertainty of the $\mathrm{HO}_{2}$ yields estimated is much larger than for the $\mathrm{OH}$ yields. For the ozonolysis of ethene, propene, 1-butene, and isobutene, the uncertainty of the $\mathrm{HO}_{2}$ yield $\beta$ was estimated to $50 \%$.

[57] To calculate the yields of the stable products formaldehyde, acetaldehyde, and $\mathrm{CO}$ numerical simulations were done using the reaction coefficients $k_{\mathrm{O}_{3}}$ and the $\mathrm{OH}$ yields $\alpha$ determined.

\section{Results and Discussion}

\subsection{Reaction Rates}

[58] Table 3 lists the scaling factors determined relative to the reaction rate coefficients recommended by Atkinson [Atkinson, 1994, 1997; Atkinson and Arey, 2003]. The recommended values were determined by averaging the absolute rate coefficients from different studies and have estimated uncertainties ranging from $25 \%$ to $35 \%$. The reaction rate coefficients of all but one alkene determined in this study agree well with the values recommended by Atkinson and Arey [2003] and deviate less than 10\% from

Table 3. Reaction Rate Coefficients of Ozonolysis of Alkenes Determined Under Dry (A) and Humid (B) Conditions Expressed as Scaling Factors of Rate Coefficients Recommended by Atkinson and Arey [2003] ${ }^{\mathrm{a}}$

\begin{tabular}{|c|c|c|c|c|c|}
\hline Alkene & Type & $F$ & $F(\mathrm{k})$ & $\begin{array}{c}k_{O_{3}}, \mathrm{~cm}^{3} \mathrm{molec}^{-1} \mathrm{~s}^{-1}[\text { Atkinson, } \\
1994 ; \text { Atkinson and Arey, 2003] }\end{array}$ & $\begin{array}{c}k_{O_{3}} \text { at } 298 \mathrm{~K}, 10^{-18} \mathrm{~cm}^{3} \mathrm{molec}^{-1} \mathrm{~s}^{-1} \\
{[\text { Atkinson, 1994] }}\end{array}$ \\
\hline \multirow[t]{2}{*}{ Ethene } & A & $1.00 \pm 0.10$ & $1.08 \pm 0.22$ & $15 \quad \frac{(-2580 \pm 71) K}{K}$ & \\
\hline & B & $1.15 \pm 0.20$ & $1.08 \pm 0.22$ & $9.14_{-0.24}^{+0.26} \times 10^{-15} \mathrm{e}$ & $1.59( \pm 30 \%)$ \\
\hline \multirow[t]{2}{*}{ Propene } & A & $0.95 \pm 0.05$ & $1.05 \pm 0.12$ & & \\
\hline & $\mathrm{B}$ & $1.15 \pm 0.05$ & $1.05 \pm 0.12$ & $5.51 \times 10^{-15} \mathrm{e}^{\frac{-1818}{T}}$ & $10.1( \pm 25 \%)$ \\
\hline \multirow[t]{2}{*}{ 1-Butene } & A & $0.95 \pm 0.05$ & $1.00 \pm 0.09$ & & \\
\hline & B & $1.05 \pm 0.05$ & $1.00 \pm 0.09$ & $3.36 \times 10^{-15} \mathrm{e}^{\frac{-1744}{T}}$ & $9.64( \pm 25 \%)$ \\
\hline \multirow[t]{2}{*}{ Isobutene } & A & $0.90 \pm 0.05$ & $0.98 \pm 0.11$ & & \\
\hline & $\mathrm{B}$ & $1.05 \pm 0.05$ & $0.98 \pm 0.11$ & $2.70 \times 10^{-15} \mathrm{e}^{\frac{-16}{1}}$ & $11.3( \pm 30 \%)$ \\
\hline \multirow[t]{3}{*}{ (Z)-Butene } & $\mathrm{A}$ & $1.05 \pm 0.05$ & $1.03 \pm 0.09$ & & \\
\hline & A & $1.00 \pm 0.05$ & $1.03 \pm 0.09$ & & \\
\hline & $\mathrm{B}$ & $1.05 \pm 0.05$ & $1.03 \pm 0.09$ & $3.22 \times 10^{-15} \mathrm{e}$ & $125( \pm 25 \%)$ \\
\hline \multirow{3}{*}{ (E)-Butene } & A & $1.25 \pm 0.05$ & $1.25 \pm 0.08$ & & \\
\hline & A & $1.20 \pm 0.05$ & $1.25 \pm 0.08$ & & \\
\hline & $\mathrm{B}$ & $1.30 \pm 0.05$ & $1.25 \pm 0.08$ & $6.64 \times 10^{-15} \mathrm{e}^{-}$ & $190( \pm 35 \%)$ \\
\hline
\end{tabular}

${ }^{\mathrm{a}} F(\mathrm{k})$ are average values of scaling factors for experiment under dry and humid conditions. Total error given is calculated from the error of the single experiments and standard deviation of repeated experiments. 
Table 4. Mean OH Yields in the Ozonolysis of Ethene, Propene, 1-Butene, (Z)-Butene, $(E)$-Butene, and Isobutene Under Dry (A) and Humid Conditions (B) Compared With Literature Values ${ }^{\mathrm{a}}$

\begin{tabular}{|c|c|c|c|c|c|}
\hline \multirow[b]{2}{*}{ Alkene } & \multicolumn{2}{|c|}{ This Study } & \multicolumn{3}{|c|}{ Literature } \\
\hline & Conditions & OH Yield & OH Yield & Humidity & Reference \\
\hline \multirow[t]{13}{*}{ Ethene } & A & $0.00 \pm 0.05$ & & & \\
\hline & $\mathrm{B}$ & $0.00 \pm 0.05$ & & & \\
\hline & & & $0.12(+0.06 /-0.04)^{\mathrm{b}}$ & $1 \mathrm{mbar}$ & Atkinson et al. [1992] \\
\hline & & & $0.1^{\mathrm{b}}$ & dry & Curley et al. [1997] \\
\hline & & & $0.08 \pm 0.01^{\mathrm{c}}$ & dry & Gutbrod et al. [1997] \\
\hline & & & $0.18 \pm 0.06^{\mathrm{d}}$ & dry & Paulson et al. [1999] \\
\hline & & & $0.14 \pm 0.04^{\mathrm{e}}$ & dry & Rickard et al. [1999] \\
\hline & & & $0.20 \pm 0.02^{\mathrm{f}}$ & dry & Mihelcic et al. [1999] \\
\hline & & & $0.22 \pm 0.06^{\mathrm{g}}$ & dry & Fenske et al. [2000] \\
\hline & & & $0.40^{\mathrm{h}}$ & dry & Kroll et al. [2001] \\
\hline & & & $0.08 \pm 0.01^{\mathrm{i}}$ & $<0.3 \mathrm{mbar}$ & Hasson et al. [2003] \\
\hline & & & $0.06 \pm 0.01^{\mathrm{j}}$ & $16 \mathrm{mbar}$ & Hasson et al. [2003] \\
\hline & & & 0.02 (calculation) & dry & Olzmann et al. [1997] \\
\hline \multirow[t]{9}{*}{ Propene } & A & $0.10 \pm 0.07$ & & & \\
\hline & B & $0.30 \pm 0.08$ & & & \\
\hline & & & $0.33(+0.16 /-0.11)^{\mathrm{b}}$ & 10 mbar & Atkinson and Aschmann [1993] \\
\hline & & & $0.18 \pm 0.04^{\mathrm{c}}$ & dry & Gutbrod et al. [1997] \\
\hline & & & $0.35 \pm 0.07^{\mathrm{d}}$ & dry & Paulson et al. [1999] \\
\hline & & & $0.32 \pm 0.08^{\mathrm{e}}$ & dry & Rickard et al. [1999] \\
\hline & & & $0.34 \pm 0.06^{\mathrm{b}}$ & dry & Neeb and Moortgat [1999] \\
\hline & & & $0.33 \pm 0.07^{\mathrm{g}}$ & dry & Fenske et al. [2000] \\
\hline & & & $0.40 \pm 0.06^{\mathrm{n}}$ & $1 \mathrm{mbar}$ & Aschmann et al. [2003] \\
\hline \multirow[t]{5}{*}{ 1-Butene } & A & $0.00 \pm 0.08$ & & & \\
\hline & $\mathrm{B}$ & $0.30 \pm 0.09$ & & & \\
\hline & & & $0.41(+0.2 /-0.13)^{\mathrm{b}}$ & $1 \mathrm{mbar}$ & Atkinson and Aschmann [1993] \\
\hline & & & $0.29 \pm 0.05^{\mathrm{d}}$ & dry & Paulson et al. [1999] \\
\hline & & & $0.23 \pm 0.04^{\mathrm{g}}$ & dry & Fenske et al. [2000] \\
\hline \multirow[t]{7}{*}{ Isobutene } & A & $0.30 \pm 0.14$ & & & \\
\hline & B & $0.80 \pm 0.10$ & & & \\
\hline & & & $0.84 \pm 0.42^{\mathrm{b}}$ & $1 \mathrm{mbar}$ & Atkinson and Aschmann [1993] \\
\hline & & & $0.72 \pm 0.12^{\mathrm{d}}$ & dry & Paulson et al. [1999] \\
\hline & & & $0.60 \pm 0.15^{\mathrm{e}}$ & dry & Rickard et al. [1999] \\
\hline & & & $0.60(+0.05 /-0.07)^{\mathrm{b}}$ & dry & Neeb and Moortgat [1999] \\
\hline & & & 0.70 (calculation) & dry & Olzmann et al. [1997] \\
\hline \multirow[t]{6}{*}{ (Z)-Butene } & A & $0.18 \pm 0.09$ & & & \\
\hline & B & $0.40 \pm 0.05$ & & & \\
\hline & & & $0.41(+0.2 /-0.13)^{\mathrm{b}}$ & $1 \mathrm{mbar}$ & Atkinson and Aschmann [1993] \\
\hline & & & $0.14 \pm 0.03^{\mathrm{k}}$ & dry & Horie et al. [1994] \\
\hline & & & $0.17 \pm 0.02^{\mathrm{c}}$ & dry & Gutbrod et al. [1997] \\
\hline & & & $0.33 \pm 0.07^{1}$ & dry & McGill et al. [1999] \\
\hline \multirow[t]{10}{*}{ (E)-Butene } & A & $0.70 \pm 0.12$ & & & \\
\hline & B & $0.60 \pm 0.12$ & & & \\
\hline & & & $0.64(+0.32 /-0.21)^{\mathrm{b}}$ & $1 \mathrm{mbar}$ & Atkinson and Aschmann [1993] \\
\hline & & & $0.24 \pm 0.05^{\mathrm{c}}$ & dry & Horie et al. [1994] \\
\hline & & & $0.24 \pm 0.02^{\mathrm{c}}$ & dry & Gutbrod et al. [1997] \\
\hline & & & $0.54 \pm 0.11^{1}$ & dry & McGill et al. [1999] \\
\hline & & & $0.67 \pm 0.19^{\mathrm{g}}$ & dry & Fenske et al. [2000] \\
\hline & & & $0.75 \pm 0.19^{\mathrm{m}}$ & $<0.2$ mbar & Siese et al. [2001] \\
\hline & & & $0.54 \pm 0.05^{\mathrm{i}}$ & $<0.3$ mbar & Hasson et al. [2003] \\
\hline & & & $0.52 \pm 0.04^{\mathrm{j}}$ & 16 mbar & Hasson et al. [2003] \\
\hline
\end{tabular}

\footnotetext{
${ }^{a}$ The error of $\alpha$ was determined from the error of model assumption, the absolute error of the experiment of $5 \%$, and the variance of repeated experiments. Humidity in the reference experiments is reported as water vapor partial pressure in mbar. In the experiments of Hasson et al. [2003], water vapor partial pressure was estimated from the relative humidity, temperature, and pressure as given in the reference. Experiments were considered as conducted under dry conditions if no data on humidity were given in the reference.

${ }^{\mathrm{b}}$ Cyclohexane scavenger, Teflon reactor.

${ }^{\mathrm{c}} \mathrm{CO}$ scavenger, glass reactor.

${ }^{\mathrm{d}}$ Small relative rate study, ethers and aromatics as tracers.

${ }^{\mathrm{e}}$ Trimethylbenzene tracer, Teflon reactor.

${ }^{\mathrm{f}}$ Measured as $\mathrm{HO}_{2}$ (MIESR) after conversion with $\mathrm{CO}$.

${ }^{\mathrm{g}}$ Trimethylbenzene, xylene as tracers.

${ }^{\mathrm{h}}$ Measured (LIF) at low pressure.

${ }^{\mathrm{i}}$ Small relative rate study, ethers and aromatics as tracers, Teflon reactor, dry.

${ }^{\mathrm{j}}$ Small relative rate study, ethers and aromatics as tracers, Teflon reactor, $65 \%$ relative humidity.

${ }^{\mathrm{k}}$ Glass reactor, no scavenger.

${ }^{1}$ Trimethylbenzene tracer, Teflon reactor.

${ }^{\mathrm{m}}$ Measured (LIF).

${ }^{\mathrm{n}} 2$, 3-Butandiol scavenger, Teflon reactor.
} 
Table 5. Mean $\mathrm{HO}_{2}$ Yields in the Ozonolysis of Ethene, Propene, 1-Butene, $(Z)$-Butene, $(E)$-Butene, and Isobutene With and Without Water $^{\mathrm{a}}$

\begin{tabular}{lcc}
\hline Alkene & Without Water & With Water \\
\hline Ethene & $0.50 \pm 0.25$ & $0.40 \pm 0.20$ \\
Propene & $1.50 \pm 0.75$ & $1.15 \pm 0.60$ \\
1-Butene & $1.60 \pm 0.80$ & $1.60 \pm 0.80$ \\
Isobutene & $2.00 \pm 1.00$ & $1.60 \pm 0.80$ \\
\hline
\end{tabular}

${ }^{\mathrm{a}}$ The error was estimated to $50 \%$.

the value specified in the literature. The reaction rate coefficient for the ozonolysis of $(E)$-butene is larger by $25 \%$, but still within the uncertainties of the literature value stated with $35 \%$.

[59] The errors are comparable with the errors of the reaction coefficients from other studies. Treacy and coworkers [Treacy et al., 1992] determined the reaction rate coefficients of the six alkenes with uncertainties from $3 \%$ for $(E)$-2-butene to $16 \%$ for isobutene measuring the ozone decay with alkenes in excess.

[60] As can be seen from the simplified reaction scheme reactions (38), ozone adds to the alkene in equimolar amounts. When side reactions are suppressed, for every reacted alkene molecule an ozone molecule is consumed. For evaluating the scaling factors determined, the profiles of the accumulated turnover of ozone and the alkene versus time were plotted together with the reaction turnover $d[$ alkene $] / d t$ as calculated form equation (41). The graphs for accumulated turnovers of the alkene and ozone are almost superimposed (Figure 2a).

\subsection{Yields of $\mathrm{OH}$ and $\mathrm{HO}_{2}$}

[61] Tables 4 and 5 summarize the $\mathrm{OH}$ and $\mathrm{HO}_{2}$ yields determined in this study. The $\mathrm{OH}$ yield observed in the ozonolysis of ethene is smaller than all values previously reported. However, in previous studies, $\mathrm{HO}_{2}$ recycling was neglected. Recycling of $\mathrm{HO}_{2}$ results in an increased $\mathrm{OH}$ yield, especially when ozonolysis yields are low as it is the case for ethene ozonolysis. Moreover, the $\mathrm{OH}$ yields determined agree with the values obtained from ab initio calculations [Gutbrod et al., 1997; Olzmann et al., 1997].

[62] In the ozonolysis of propene, 1-butene, isobutene, and $(Z)$-butene $\mathrm{OH}$ yields were increased under humid conditions compared to experiments in the dry chamber. The influence of humidity on the $\mathrm{OH}$ yields has already been proposed in model calculations [Anglada et al., 2002; Paulson et al., 1992], but was not observed in experimental studies. The OH yields of ozonolysis observed in this study are difficult to compare with the results of previous studies because in many experiments the exact humidity of the reactor is not given. [Atkinson and Aschmann, 1993] conducted their experiments with clean air of a water vapor partial pressure of less than 1.25 mbar. However, even this small amount of humidity may affect the $\mathrm{OH}$ yield. Furthermore, it is remarkable that the experiments, in which the smallest $\mathrm{OH}$ yields were obtained [Gutbrod et al., 1997; Horie et al., 1994], were conducted in a glass reactor. All other experiments listed in Table 4 were conducted in Teflon reactors, which are prone to introduction of water by permeation. Teflon surfaces have to be flushed extensively to remove water. In the SAPHIR chamber per- meation of water into the chamber is avoided by a double Teflon wall with the interspace being always flushed with synthetic air. If furthermore reactors have only a small volume to surface ratio, even a small amount of water may lead to an increased $\mathrm{OH}$ yield. In fact, if experiments conducted in Teflon reactors are regarded as experiments under humid conditions, there is a good agreement of the $\mathrm{OH}$ yield determined in this study with the results of previous studies.

[63] Differences in $\mathrm{OH}$ yields in the ozonolysis of substituted alkenes can be derived from stereochemistry of the alkenes which is reflected in different Criegee intermediates. The addition of ozone on alkenes (1) results in an ozonide. This compound is a five-membered ring which is believed to have an envelope shape. The configuration of the ozonide is thought to reflect the configuration of the reactants. $(E)$-Alkenes $\left(1, \mathrm{R}_{2}\right.$ $=\mathrm{H})$ yield trans-ozonides $\left(\mathrm{R}_{2}=\mathrm{H}\right)$, while $(Z)$-alkenes $\left(1, \mathrm{R}_{3}=\right.$ $\mathrm{H})$ react to cis-ozonides $\left(\mathrm{R}_{3}=\mathrm{H}\right)$. The stereochemistry of the Criegee intermediate produced by cleavage of the ozonide (2) is determined by the configuration of the transition state. However, energy differences between different transition states leading to different Criegee intermediates are subtle and difficult to predict. Usually, ozonide cleavage will produce mixtures of Criegee radicals and carbonyls rather than two predominant products.

[64] In contrast to isobutene, which reacts to a Criegee intermediate with methyl groups both in syn and anti position $\left(32, \mathrm{R}_{1}=\mathrm{CH}_{3}\right)$, the ozonides of propene and 1-butene may either decompose to syn-Criegee or to antiCriegee radicals. For the latter the hydroperoxide channel [Horie and Moortgat, 1991] (33) is not energetically accessible under dry conditions which explains the smaller $\mathrm{OH}$ yield compared to isobutene. However, under humid conditions, water may also add to anti-Criegee intermediates $\left(30, \mathrm{R}_{1}=\mathrm{CH}_{3}, \mathrm{R}_{2}=\mathrm{H}\right)$ to form an $\alpha$-hydroxy hydroperoxide which releases $\mathrm{OH}$ after decomposing. Criegee radicals derived from ethene $\left(30, R_{1}=R_{2}=H\right)$ can also form water complexes but the activation enthalpy is even larger than for anti- $\mathrm{CH}_{3} \mathrm{HCOO}$ [Anglada et al., 2002].

[65] (Z)-butene and (E)-butene are believed to form mixtures of anti-Criege and syn-Criegee intermediates. Differences in composition of the Criegee intermediates may account for the different $\mathrm{OH}$ yields observed.

[66] At first glance, the influence of humidity on $\mathrm{OH}$ production in ozonolysis observed in this study seems to contradict to the results of previous studies, in which no influence of humidity on the $\mathrm{OH}$ yields in alkene ozonolysis was observed. However, in these studies either ozonolysis of alkenes different from the alkenes in our study was examined (e.g., terpenes [Aschmann et al., 2002]) or the humidity in the reactor was too high to enable a comparison of the $\mathrm{OH}$ yields with the results obtained under dry conditions in our study [Atkinson and Aschmann, 1993]. In the study of Hasson et al. [2003] ozonolysis experiments with two alkenes were conducted (ethene and ( $Z$ )-butene) and no influence of the humidity on the $\mathrm{OH}$ yields was observed. The alkenes chosen in their study might not be representative for all alkenes, because in our study an increased water vapor partial pressure did also not effect $\mathrm{OH}$ production in the ozonolysis of ethene. The effect of humidity on the $\mathrm{OH}$ production of $(E)$-butene ozonolysis was also small, in contrast to other alkenes examined. 
Table 6. Mean Formaldehyde Yields in the Ozonolysis of Ethene, 1-Butene, and Isobutene Under Different Conditions

\begin{tabular}{|c|c|c|c|c|}
\hline \multirow[b]{2}{*}{ Alkene } & \multicolumn{2}{|c|}{ This Study } & \multicolumn{2}{|c|}{ Literature } \\
\hline & Type $^{\mathrm{a}}$ & $\mathrm{HCHO}$ & HCHO Yield & Reference \\
\hline Ethene & $\begin{array}{l}\text { B } \\
\text { C } \\
\text { D }\end{array}$ & $\begin{array}{l}1.00 \pm 0.08 \\
1.00 \pm 0.08 \\
0.88 \pm 0.08\end{array}$ & $\begin{array}{c}0.618^{\mathrm{b}} \\
1.060 \pm 0.071^{\mathrm{c}} \\
0.992 \pm 0.061^{\mathrm{c}} \\
0.92^{\mathrm{d}}\end{array}$ & $\begin{array}{c}\text { Horie and Moortgat }[1991] \\
\text { Grosjean et al. }[1996] \\
\text { Grosjean and Grosjean [1996a] } \\
\text { Neeb et al. }[1998]\end{array}$ \\
\hline 1-Butene & $\begin{array}{l}\text { A } \\
\text { B }\end{array}$ & $\begin{array}{l}0.80 \pm 0.06 \\
0.86 \pm 0.06\end{array}$ & $0.630 \pm 0.031^{\mathrm{c}}$ & Grosjean et al., [1996] \\
\hline Isobutene & $\begin{array}{l}\text { A } \\
\text { B }\end{array}$ & $\begin{array}{l}1.80 \pm 0.14 \\
1.67 \pm 0.14\end{array}$ & $\begin{array}{c}0.95 \pm 0.098^{\mathrm{c}} \\
1.01 \pm 0.07^{\mathrm{e}} \\
1.40^{\mathrm{d}} \\
1.21 \pm 0.13^{\mathrm{e}} \\
0.97 \pm 0.11^{\mathrm{f}}\end{array}$ & $\begin{array}{c}\text { Grosjean et al., [1996] } \\
\text { Tuazon et al. }[1997] \\
\text { Sauer et al. }[1999] \\
\text { Neeb and Moortgat [1999] } \\
\text { Neeb and Moortgat [1999] }\end{array}$ \\
\hline $\begin{array}{l}{ }^{\mathrm{a}} \text { A, with } \\
{ }^{\mathrm{b}} \text { Pyrex } 1 \\
{ }^{\mathrm{c}} \text { Teflon } \\
{ }^{\mathrm{d}} \text { Glass r } \\
{ }^{\mathrm{e}} \text { Teflon } \\
{ }^{\mathrm{f}} \text { Teflon }\end{array}$ & $\begin{array}{l}\text { and } \mathrm{CO} \\
\% \text { relati } \\
\text {, cyclol } \\
\mathrm{CO} \text { as }\end{array}$ & $\begin{array}{l}\text { ter only; C, } \\
\text { cyclohexan } \\
\text { avenger. }\end{array}$ & $\begin{array}{l}\text { ly; and } \mathrm{D} \text {, wit } \\
\text { ger. }\end{array}$ & CO. \\
\hline
\end{tabular}

[67] The ozonolysis yields of $\mathrm{HO}_{2}$ determined are listed in Table 5. In the literature there is only one work we are aware of in which $\mathrm{HO}_{2}$ yields of have been measured in ozonolysis experiments. In this study [Mihelcic et al., 1999] $\mathrm{HO}_{2}$ radical mixing ratios were determined by means of matrix isolation and electron spin resonance and an $\mathrm{HO}_{2}$ yield of 0.4 in the ozonolysis of ethene was observed. However, in the chemical gas phase mechanism RACM [Stockwell et al., 1997] $\mathrm{HO}_{2}$ yield of alkene ozonolysis is assumed to be 0.25 . Regardless of the rather large experimental uncertainties of $50 \%$, the results of the present study indicate that alkene ozonolysis is a stronger source of $\mathrm{HO}_{2}$ than previously expected. Because of high uncertainties in the $\mathrm{HO}_{2}$ yields determined deriving a trend is difficult. However, the $\mathrm{HO}_{2}$ yield in the ozonolysis of the unsubstituted ethene is smaller than in the reaction of the single substituted alkenes propene and 1-butene. The highest $\mathrm{HO}_{2}$ yield was observed in the ozonolysis of the double substituted isobutene.

\subsection{Yields of Stable Products}

\subsubsection{Formaldehyde Yield $\delta$}

[68] In addition, formaldehyde is also a product of the reaction of methylperoxy radical with other peroxy radicals. In the experiments it was not possible to distinguish between formaldehyde production by ozonolysis and by reaction of methyl peroxy radicals. The formaldehyde yields in the ozonolysis of ethene, 1-butene, and isobutene for which additional formaldehyde production by methyl peroxy radicals is not expected are listed in Table 6. The formaldehyde yields in the ozonolysis experiments of propene, $(Z)$-butene, and $(E)$-butene for which production of methylperoxy radicals is reported (Table 7) depend on the $\mathrm{HO}_{2}$ and $\mathrm{RO}_{2}$ yields $\left(\beta\right.$ and $\gamma$ in reaction (38)). Since $\mathrm{RO}_{2}$ was not measured and the $\mathrm{HO}_{2}$ yields of the 2-butenes could not be determined formaldehyde yields can only be calculated depending on $\mathrm{RO}_{2}$ yields $\gamma$ and $\mathrm{HO}_{2}$ yields $\beta$ (Table 7).

[69] In all experiments the formaldehyde concentration was well above the detection limit of the instrument. The deviation between the experimental data and data from the numerical simulation was always less than 5\% (Figure $5 \mathrm{~b}$ ). The errors of the yields specified in Table 6 result from measurement uncertainties and the deviation from the numerical simulations. Standard deviations of repeated experiments were better than $2 \%$.

[70] In ozonolysis experiments with ethene the yield of formaldehyde was within the experimental errors which corresponds to the results in earlier studies [Grosjean et al., 1996; Grosjean and Grosjean, 1996a; Neeb et al., 1998]. However, smaller formaldehyde yields were reported in an earlier study [Horie and Moortgat, 1991] where no scavengers were added.

[71] The ozonolysis of both 1-butene and isobutene yielded more formaldehyde than previously observed [Grosjean et al., 1996; Sauer et al., 1999; Tuazon et al., 1997]. In the case of isobutene the yield was even larger than 1 and considerably larger than found in other studies.

[72] The values listed are average values of experiments under dry and humid conditions. Formaldehyde yields for each combination of $\gamma$ and $\beta$ have errors of $8 \%$. Since in the references formaldehyde produced from ozonolysis is usually not distinguished from formaldehyde production by methylperoxide reaction [Grosjean et al., 1996; Horie et al., 1997; Tuazon et al., 1997], values reported in the references were compared to the yields obtained with $\gamma=0$. As for 1-butene and isobutene, the yields obtained in this study are higher than the literature values.

3.3.2. Acetaldehyde Yield $\varepsilon$

[73] As formaldehyde, acetaldehyde is either formed as primary carbonyl or derived from the Criegee intermediates. 
Table 7. Mean Formaldehyde Yields in the Ozonolysis of Propene, $(Z)$-Butene and $(E)$-Butene Calculated for Different $\mathrm{HO}_{2}$ Yields $(\beta)$ and Alkylperoxy Radical Yields $(\gamma)$

\begin{tabular}{|c|c|c|c|c|c|}
\hline \multirow[b]{2}{*}{ Alkene } & \multicolumn{3}{|c|}{ This Study } & \multicolumn{2}{|c|}{ Literature } \\
\hline & $\beta$ & $\gamma$ & $\mathrm{HCHO}$ yield & $\mathrm{HCHO}$ yield & Reference \\
\hline \multirow[t]{7}{*}{ Propene } & 0.20 & 0.00 & 0.80 & & \\
\hline & 0.20 & 0.50 & 0.54 & & \\
\hline & 0.20 & 1.00 & 0.30 & & \\
\hline & 1.00 & 0.00 & 0.82 & & \\
\hline & 1.00 & 0.50 & 0.70 & & \\
\hline & 1.00 & 1.00 & 0.53 & & \\
\hline & & & & $\begin{array}{c}0.490^{\mathrm{a}} \\
0.780 \pm 0.015^{\mathrm{b}} \\
0.645 \pm 0.048^{\mathrm{c}}\end{array}$ & $\begin{array}{c}\text { Horie and Moortgat [1991] } \\
\text { [Grosjean et al., 1996] } \\
\text { [Tuazon et al., 1997] }\end{array}$ \\
\hline \multirow[t]{10}{*}{ (Z)-Butene } & 0.20 & 0.00 & 0.25 & & \\
\hline & 0.20 & 0.50 & 0.03 & & \\
\hline & 0.20 & 0.58 & 0.00 & & \\
\hline & 1.00 & 0.00 & 0.25 & & \\
\hline & 1.00 & 0.50 & 0.18 & & \\
\hline & 1.00 & 1.00 & 0.02 & & \\
\hline & 1.00 & 1.00 & & $0.17^{\mathrm{d}}$ & [Horie et al., 1994] \\
\hline & & & & $0.126 \pm 0.019^{\mathrm{e}}$ & [Grosjean et al., 1996] \\
\hline & & & & $0.18^{\mathrm{d}}$ & [Horie et al., 1997] \\
\hline & & & & $0.161 \pm 0.030^{\mathrm{c}}$ & [Tuazon et al., 1997] \\
\hline \multirow[t]{10}{*}{ (E)-Butene } & 0.20 & 0.00 & 0.25 & & \\
\hline & 0.20 & 0.50 & 0.00 & & \\
\hline & 1.00 & 0.00 & 0.28 & & \\
\hline & 1.00 & 0.50 & 0.15 & & \\
\hline & 1.00 & 0.90 & 0.00 & & \\
\hline & & & & $0.164^{\mathrm{a}}$ & Horie and Moortgat [1991] \\
\hline & & & & $0.29^{\mathrm{d}}$ & [Horie et al., 1994] \\
\hline & & & & $0.126 \pm 0.019^{\mathrm{e}}$ & [Grosjean et al., 1996] \\
\hline & & & & $0.28^{\mathrm{d}}$ & [Horie et al., 1997] \\
\hline & & & & $0.168 \pm 0.015^{\mathrm{c}}$ & [Tuazon et al., 1997] \\
\hline
\end{tabular}

${ }^{\text {a }}$ yyrex reactor, dry

${ }^{\mathrm{b}}$ Teflon reactor, $55 \%$ relative humidity, cyclohexane as scavenger.

${ }^{\mathrm{c}}$ Teflon reactor, dry, cyclohexane as scavenger.

${ }^{\mathrm{d}}$ Glass reactor, dry.

${ }^{\mathrm{e}}$ Teflon reactor, dry, cyclohexane as scavenger, mixture of $40 \%(Z)$-butene and $60 \%(E)$-butene.

In contrast to formaldehyde, acetaldehyde is not assumed to be generated from reactions of methyl peroxy radicals. Table 8 lists acetaldehyde yields measured under different conditions. The acetaldehyde mixing ratio measured was between 5 and $20 \mathrm{ppbV}$ and the absolute measurement error below 20\%. The deviations between the measured and numerically modeled mixing ratios were estimated to be less than 5\% (Figure 5c), which results in an overall error of $20 \%$.
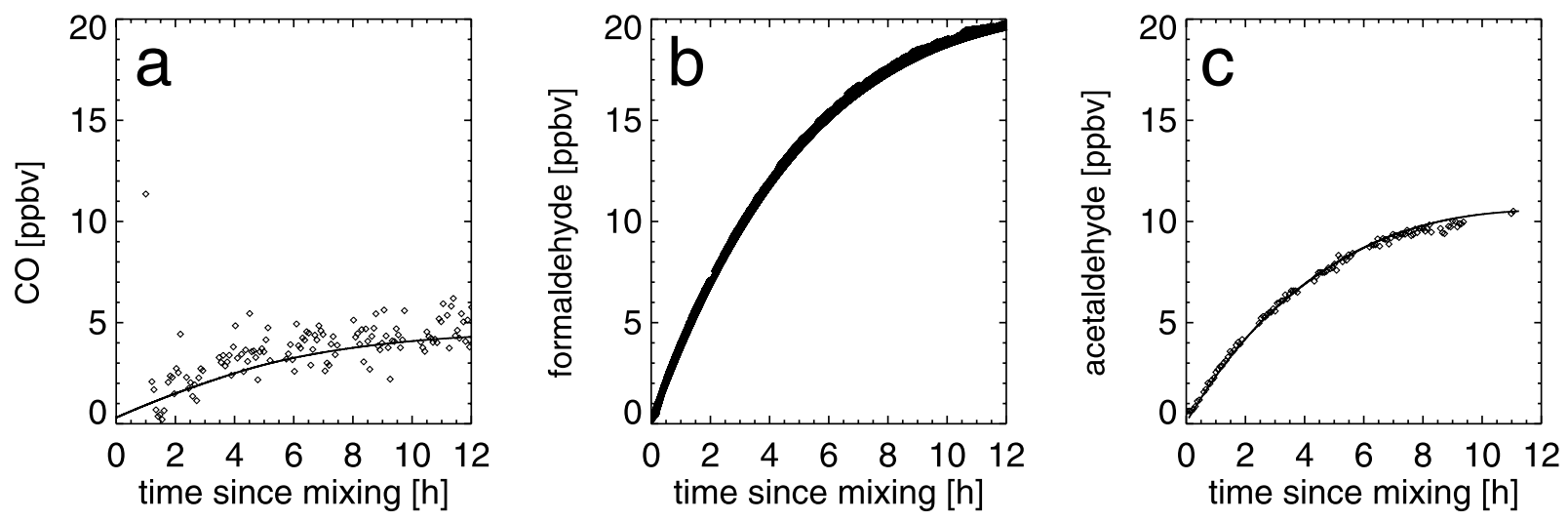

Figure 5. Measured (diamonds) mixing ratios and mixing ratios calculated from numerical simulations (black line): (a) CO mixing ratio in the ethene ozonolysis, experiment 1, dry conditions; (b) formaldehyde mixing ratio in the ozonolysis of ethene, experiment 2 , humid conditions; and (c) acetaldehyde mixing ratio in the ozonolysis of propene, experiment 8 , humid conditions. 
Table 8. Mean Acetaldehyde Yields in the Ozonolysis of Propene, $(Z)$-Butene and (E)-Butene Under Different Conditions

\begin{tabular}{|c|c|c|c|c|}
\hline \multirow[b]{2}{*}{ Alkene } & \multicolumn{2}{|c|}{ This Study } & \multicolumn{2}{|c|}{ Literature } \\
\hline & Type $^{\mathrm{a}}$ & Acetaldeyhde Yield & Acetaldehyde Yield & Reference \\
\hline \multirow[t]{8}{*}{ Propene } & $\mathrm{A}$ & $0.55 \pm 0.11$ & & \\
\hline & B & $0.53 \pm 0.10$ & & \\
\hline & $\mathrm{C}$ & $0.47 \pm 0.09$ & & \\
\hline & $\mathrm{D}$ & $0.53 \pm 0.10$ & & \\
\hline & & & $0.394^{\mathrm{b}}$ & Horie and Moortgat [1991] \\
\hline & & & $0.520 \pm 0.026^{\mathrm{c}}$ & [Grosjean et al., 1996] \\
\hline & & & $0.446 \pm 0.092^{\mathrm{d}}$ & [Tuazon et al., 1997] \\
\hline & & & $0.34 \pm 0.01^{\mathrm{e}}$ & [Rickard et al., 1999] \\
\hline \multirow[t]{8}{*}{ (Z)-Butene } & A & $1.65 \pm 0.33$ & & \\
\hline & B & $1.20 \pm 0.24$ & & \\
\hline & & & $1.2^{\mathrm{f}}$ & [Horie et al., 1994] \\
\hline & & & $1.150 \pm 0.104^{\mathrm{g}}$ & [Grosjean et al., 1996] \\
\hline & & & $1.08 \pm 0.08^{\mathrm{e}}$ & [Tuazon et al., 1997] \\
\hline & & & $1.2^{\mathrm{f}}$ & [Horie et al., 1997] \\
\hline & & & $0.83 \pm 0.08^{\mathrm{e}}$ & [Rickard et al., 1999] \\
\hline & & & $0.86 \pm 0.03^{\mathrm{h}}$ & [McGill et al., 1999] \\
\hline \multirow{12}{*}{ (E)-Butene } & A & $1.50 \pm 0.30$ & & \\
\hline & B & $1.50 \pm 0.30$ & & \\
\hline & $\mathrm{C}$ & $1.05 \pm 0.21$ & & \\
\hline & $\mathrm{D}$ & $1.00 \pm 0.20$ & & \\
\hline & & & $1.17^{\mathrm{b}}$ & Horie and Moortgat [1991] \\
\hline & & & $\begin{array}{c}1.3^{\mathrm{t}} \\
1.150 \pm 0.104^{\mathrm{g}}\end{array}$ & $\begin{array}{c}{[\text { Horie et al., 1994] }} \\
{[\text { Grosiean et al., 1996] }}\end{array}$ \\
\hline & & & $1.3^{\mathrm{f}}$ & [Horie et al., 1997] \\
\hline & & & $1.09 \pm 0.09^{\mathrm{e}}$ & [Tuazon et al., 1997] \\
\hline & & & $0.85 \pm 0.07^{\mathrm{h}}$ & [McGill et al., 1999] \\
\hline & & & $0.98 \pm 0.20^{\mathrm{e}}$ & [Rickard et al., 1999] \\
\hline & & & $0.97^{\mathrm{e}}$ & [Hasson et al., 2001] \\
\hline & & & $1.17^{\mathrm{i}}$ & [Hasson et al., 2001] \\
\hline
\end{tabular}

\footnotetext{
${ }^{\mathrm{a}} \mathrm{A}$, without water and $\mathrm{CO}$; $\mathrm{B}$, with water only; $\mathrm{C}$, with $\mathrm{CO}$ only; and $\mathrm{D}$, with water and $\mathrm{CO}$.

${ }^{\mathrm{b}}$ Pyrex reactor, dry.

${ }^{\mathrm{c}}$ Teflon reactor, $55 \%$ relative humidity, cyclohexane as scavenger.

${ }^{\mathrm{d}}$ Teflon reactor, $5 \%$ relative humidity, cyclohexane as scavenger.

${ }^{\mathrm{e}}$ Teflon reactor, dry, cyclohexane as scavenger.

${ }^{\mathrm{f}}$ Glass reactor, dry.

${ }^{\mathrm{g}}$ Teflon reactor, $55 \%$ relative humidity, cyclohexane as scavenger, mixture of $40 \%(Z)$-butene and $60 \%(E)$-butene.

${ }^{\mathrm{h}}$ Glass reactor, dry, cyclohexane as scavenger.

${ }^{\mathrm{i}}$ Teflon reactor, humid, cyclohexane as scavenger.
}

[74] The acetaldehyde yields of propene and $(E)$-butene ozonolysis with $\mathrm{CO}$ as scavenger agree with the values reported in the literature (Table 8) within the experimental uncertainties. For propene, the acetaldehyde yield was independent of water vapor partial pressure and $\mathrm{CO}$ mixing ratio. When $\mathrm{CO}$ was not added to $(E)$-butene, the acetaldehyde yield was considerably higher than with radicals quenched (Table 8).

[75] As for propene, there is no influence of humidity on the acetaldehyde yield in the ozonolysis of $(E)$-butene. In contrast, acetaldehyde yield from ( $Z$ )-butene ozonolysis in the humid chamber was smaller than in the dry chamber.

\subsubsection{Carbon Monoxide Yields $\phi$}

[76] Formation of carbon monoxide was between $1 \mathrm{ppb}$ and $5 \mathrm{ppb}$ approximately at the limit of quantification, which leads to an error of about $50 \%$ for the measurements (Figure 5a). For adapting the model only the time was used when the $\mathrm{CO}$ production was larger than the $\mathrm{CO}$ loss by flushing the chamber to avoid errors due to uncertainties in the dilution rate. $\mathrm{CO}$ yields in the ozonolysis of ethene and (E)-butene estimated in this study are smaller compared to the yields stated in the references. Regardless of the large uncertainties in the values (Table 9), there is a trend toward smaller CO yields under humid conditions for all alkenes except ethene.

\section{Summary}

[77] The yields of $\mathrm{OH}, \mathrm{HO}_{2}$, formaldehyde, acetaldehyde, and $\mathrm{CO}$ in the ozonolysis of six short-chained alkenes were determined in atmospheric concentrations. Experiments were conducted in the atmosphere simulation chamber SAPHIR. Ozonolysis experiments were conducted with and without $\mathrm{CO}$ as an $\mathrm{OH}$ scavenger and under humid and dry conditions. Reaction rate coefficients determined for ozonolysis were in accordance with the literature values [Atkinson, 1997]. From the deviation in the turnover of alkenes in the ozonolysis with scavengers compared to the turnover without scavengers $\mathrm{OH}$ yields were determined. The $\mathrm{OH}$ yields depend on the humidity and on the alkene. In the ozonolysis of ethene, unsubstituted Criegee radicals are generated which do not cleave $\mathrm{OH}$ radicals neither in dry nor in a humid atmosphere. In the ozonolysis of monosubstituted alkenes, as propene and 1-butene, water promotes $\mathrm{OH}$ generation, possibly due to reaction with the anti-Criegee intermediate formed, while ozonolysis of isobutene, which produces a Criegee interme- 
Table 9. Mean CO Yields in the Ozonolysis of Ethene, Propene, 1-Butene, $(Z)$-Butene, $(E)$-Butene, and Isobutene Under Dry (A) and Humid (B) Conditions

\begin{tabular}{|c|c|c|c|c|}
\hline \multirow[b]{2}{*}{ Alkene } & \multicolumn{2}{|c|}{ This Study } & \multicolumn{2}{|c|}{ Literature } \\
\hline & Type & CO Yield & CO Yield & Reference \\
\hline \multirow[t]{2}{*}{ Ethene } & A & $0.20 \pm 0.10$ & & \\
\hline & B & $0.20 \pm 0.10$ & $0.250^{\mathrm{a}}$ & Horie and Moortgat [1991] \\
\hline \multirow[t]{2}{*}{ Propene } & $\begin{array}{l}\mathrm{A} \\
\mathrm{B}\end{array}$ & $\begin{array}{l}0.33 \pm 0.17 \\
0.25 \pm 0.13\end{array}$ & & \\
\hline & & & $\begin{array}{c}0.198^{\mathrm{a}} \\
0.276 \pm 0.031^{\mathrm{b}}\end{array}$ & $\begin{array}{c}\text { Horie and Moortgat [1991] } \\
{[\text { Tuazon et al., 1997] }}\end{array}$ \\
\hline 1-Butene & $\begin{array}{l}\mathrm{A} \\
\mathrm{B}\end{array}$ & $\begin{array}{l}0.17 \pm 0.09 \\
0.10 \pm 0.05\end{array}$ & & \\
\hline \multirow[t]{2}{*}{ Isobutene } & $\begin{array}{l}\mathrm{A} \\
\mathrm{B}\end{array}$ & $\begin{array}{l}0.17 \pm 0.09 \\
0.10 \pm 0.05\end{array}$ & & \\
\hline & & & $\begin{aligned} 0.093 & \pm 0.011^{\mathrm{b}} \\
0.15 & \pm 0.02^{\mathrm{b}}\end{aligned}$ & $\begin{array}{c}\text { [Tuazon et al., 1997] } \\
\text { [Neeb and Moortgat, 1999] }\end{array}$ \\
\hline \multirow[t]{2}{*}{ (Z)-Butene } & $\begin{array}{l}\mathrm{A} \\
\mathrm{B}\end{array}$ & $\begin{array}{l}0.18 \pm 0.09 \\
0.12 \pm 0.06\end{array}$ & & \\
\hline & & & $\begin{array}{c}0.21^{\mathrm{c}} \\
0.20^{\mathrm{c}} \\
0.244 \pm 0.034^{\mathrm{b}}\end{array}$ & $\begin{array}{c}\text { [Horie et al., 1994] } \\
{[\text { Horie et al., 1997] }} \\
\text { [Tuazon et al., 1997] }\end{array}$ \\
\hline \multirow[t]{2}{*}{ (E)-Butene } & $\begin{array}{l}\text { A } \\
\text { B }\end{array}$ & $\begin{array}{l}0.16 \pm 0.08 \\
0.08 \pm 0.04\end{array}$ & & \\
\hline & & & $\begin{array}{c}0.216^{\mathrm{a}} \\
0.29^{\mathrm{c}} \\
0.30^{\mathrm{c}} \\
0.217 \pm 0.026^{\mathrm{b}}\end{array}$ & $\begin{array}{c}\text { Horie and Moortgat [1991] } \\
{[\text { Horie et al., 1994] }} \\
{[\text { Horie et al., 1997] }} \\
\text { [Tuazon et al., 1997] }\end{array}$ \\
\hline
\end{tabular}

diate with a methyl group in the syn position, yields $\mathrm{OH}$ radicals even without water being present.

[78] Although the uncertainties in the determination of $\mathrm{HO}_{2}$ yields are high, there is a trend toward higher $\mathrm{HO}_{2}$ yields for higher alkenes. The values determined for propene, 1-butene and isobutene are higher than expected and may be relevant in modeling studies.

\section{References}

Anglada, J. M., J. M. Bofill, S. Olivella, and A. Solé (1996), Unimolecular isomerizations and oxygen atom loss in formaldehyde and acetaldehyde carbonyl oxides. A theoretical investigation, J. Am. Chem. Soc., 118, 4634-4647.

Anglada, J. M., R. Crehuet, and J. M. Bofill (1999), The ozonolysis of ethylene: A theoretical study of the gas-phase reaction mechanism, Chem. Eur. J., 5, 1809-1822.

Anglada, J. M., P. Aplincourt, J. M. Bofill, and D. Cremer (2002), Atmospheric formation of $\mathrm{OH}$ radicals and $\mathrm{H}_{2} \mathrm{O}_{2}$ from alkene ozonolysis under humid conditions, Chem. Phys. Chem., 3, 215-221.

Aplincourt, P., and J. M. Anglada (2003), Theoretical studies on isoprene ozonolysis under tropospheric conditions. 1. Reaction of substituted carbonyl oxides with water, J. Phys. Chem. A, 107, 5798-5811.

Aschmann, S. M., J. Arey, and R. Atkinson (2002), OH radical formation from the gas-phase reactions of $\mathrm{O}_{3}$ with a series of terpenes, Atmos. Environ., 36, 4347-4355.

Aschmann, S. M., E. C. Tuazon, J. Arey, and R. Atkinson (2003), Products of the gas-phase reaction of $\mathrm{O}_{3}$ with cylohexene, J. Phys. Chem. A, 107, $2247-2255$.

Atkinson, R. (1994), Gas-phase tropospheric chemistry of organic compounds, J. Phys. Chem. Ref. Data Monogr., 2, 1-41.

Atkinson, R. (1997), Gas-phase tropospheric chemistry of volatile organic compounds: 1. Alkanes and alkenes, J. Phys. Chem. Ref. Data, 26, $215-$ 290.

Atkinson, R., and J. Arey (2003), Atmospheric degradation of volatile organic compounds, Chem. Rev., 103, 4605-4638.

Atkinson, R., and S. M. Aschmann (1993), OH radical production from the gas-phase reactions of $\mathrm{O}_{3}$ with a series of alkenes under atmospheric conditions, Environ. Sci. Technol., 27, 1357-1363.
Atkinson, R., S. M. Aschmann, J. Arey, and B. Shorees (1992), Formation of $\mathrm{OH}$ radicals in the gas-phase reaction of $\mathrm{O}_{3}$ with a series of terpenes, J. Geophys. Res., 97, 6065-6073.

Baker, J., S. M. Aschmann, J. Arey, and R. Atkinson (2001), Reactions of stabilized Criegee intermediates from the gas-phase reactions of $\mathrm{O}_{3}$ with selected alkenes, Int. J. Chem. Kinet., 34, 73-85.

Chan, W.-T., and I. P. Hamilton (2003), Mechanisms of the ozonolysis of ethene and propene: Reliability of quantum chemical predictions, J. Chem. Phys., 118, 1688-1701.

Chew, A. A., and R. Atkinson (1996), OH radical formation yields from the gas-phase reactions of $\mathrm{O}_{3}$ with alkenes and monoterpenes, J. Geophys. Res., 101, 28,649-28,653.

Cremer, D. (1979), Theoretical determination of molecular structure and conformation. 6. The Criegee Intermediate. Evidence for a stabilization of its syn form by alkyl substituents, J. Am. Chem. Soc., 101, 7199-7205. Criegee, R., and G. Schröder (1960), Ein kristallisiertes Primärozonid, Chem. Ber., 93, 689-700.

Curley, M., M. Gurrie, J. Treacy, and H. Sidebottom (1997), Hydroxyl radical production in the gasphase reactions of ozone with alkenes, in The Oxidizing Capacity of the Troposphere: Proceedings of the 7th European Symposium on Physico-Chemical Behaviour of Atmospheric Pollutants, Venice, 1996, edited by B. Larsen, B. Versino, and G. Angeletti, pp. 74-76, Eur. Comm., Brussels.

Curtis, A., and W. P. Sweetenham (1987), Facsimilie/Chekmat user's manual, Comput. Sci. and Syst. Div., Harvell Lab., Oxford, U. K.

Fenske, J. D., A. S. Hasson, S. E. Paulson, K. T. Kuwata, A. Ho, and K. N. Houk (2000), The pressure dependence of the OH-radical yield from ozone-alkene reactions, J. Phys. Chem. A, 104, 7821-7833.

Grosjean, E., and D. Grosjean (1996a), Carbonyl products of the gas phase reaction of ozone with symmetrical alkenes, Environ. Sci. Technol., 30, 2036-2044

Grosjean, E., and D. Grosjean (1996b), Carbonyl products of the gas-phase reaction of ozone with 1-alkenes, Atmos. Environ., 30, 4107-4113.

Grosjean, E., J. B. De Andrade, and D. Grosjean (1996), Carbonyl products of the gas-phase reaction of ozone with simple alkenes, Environ. Sci. Technol., 30, 975-983.

Gutbrod, R., S. Meyer, M. M. Rahman, and R. N. Schindler (1997), On the use of $\mathrm{CO}$ as scavenger for $\mathrm{OH}$ radicals in the ozonolysis of simple alkenes and isoprene, Int. J. Chem. Kinet., 29, 717-723.

Hasson, A. S., G. Orzechowska, and S. E. Paulson (2001), Production of stabilized Criegee intermediates and peroxides in the gas phase ozono- 
lysis of alkenes: 1: Ethene, trans-2-butene, and 2,3-dimethyl-2-butene, J. Geophys. Res., 106, 34,131-34,142.

Hasson, A. S., M. Y. Chung, K. T. Kuwata, A. D. Converse, D. Krohn, and S. E. Paulson (2003), Reaction of Criegee intermediates with water vapor-An additional source of $\mathrm{OH}$ radicals in alkene ozonolysis? J. Phys. Chem. A, 107, 6176-6182.

Horie, O., and G. K. Moortgat (1991), Decomposition pathways of excited Criegee intermediates in the ozonolysis of simple alkenes, Atmos. Environ., Part A, 25, 1881-1896.

Horie, O., P. Neeb, and G. K. Moortgat (1994), Ozonolysis of trans-2-butenes and cis-2-butenes in low parts-per-million concentration ranges, Int. J. Chem. Kinet., 26, 1075-1094.

Horie, O., P. Neeb, and G. K. Moortgat (1997), The reactions of the Criegee intermediate $\mathrm{CH}_{3} \mathrm{CHOO}$ in the gas-phase ozonolysis of 2-butene isomers, Int. J. Chem. Kinet., 29, 461-468, 1997.

Johnson, D., A. G. Lewin, and G. Marston (2001), The effect of Criegeeintermediate scavengers on the $\mathrm{OH}$ yield from the reaction of ozone with 2-methylbut-2-ene, J. Phys. Chem. A, 105, 2933-2935.

Kelly, T. J., and C. R. Fortune (1994), Continuous monitoring of gaseous formaldehyde using an improved fluorescence approach, Intern. J. Environ. Anal. Chem., 54, 249-263.

Komenda, M., A. Schaub, and R. Koppmann (2003), Description and characterization of an on-line system for long-term measurements of isoprene, methyl vinyl ketone, and methacrolein in ambient air, J. Chromatogr. A, 995, 185-201.

Krinke, S. M. W. (1999), Experimentelle Bestimmung der Depositionsgeschwindigkeit von Formaldehyd und Ozon über einem Laubwaldbestand, Ph.D. thesis, Univ. Stuttgart, Stuttgart, Germany.

Kroll, J. H., J. S. Clarke, N. M. Donahue, J. G. Anderson, and K. L. Demerjian (2001), Mechanism of $\mathrm{HO}_{\mathrm{x}}$ formation in the gas-phase ozone-alkene reaction. 1. Direct, pressure-dependent measurements of prompt $\mathrm{OH}$ yields, J. Phys. Chem. A, 105, 1554-1560.

Kroll, J. H., N. M. Donahue, V. J. Cee, K. L. Demerjian, and J. G. Anderson (2002), Gas-phase ozonolysis of alkenes: Formation of $\mathrm{OH}$ from anti carbonyl oxides, J. Am. Chem. Soc., 124, 8518-8519.

Kuwata, K. T., K. L. Templeton, and A. S. Hasson (2003), Computational studies of the chemistry of syn acetaldehyde oxide, J. Phys. Chem. A, 107, 11,525-11,532.

Lindinger, W., A. Hansel, and A. Jordan (1998), On-line monitoring of volatile organic compounds at pptv levels by means of proton-transferreaction mass spectrometry (PTR-MS): Medical applications, food control and environmental research, Int. J. Mass Spectrom., 173, 191-241.

Martinez, R. I., and J. T. Herron (1988), Stopped-flow studies of the mechanisms of ozone-alkene reactions in the gas phase: Trans-2-butene, J. Phys. Chem., 92, 4644-4648.

McGill, C. D., A. R. Rickard, D. Johnson, and G. Marston (1999), Product yields in the reactions of ozone with $Z$-but-2-ene, E-but-2-ene and 2-methylbut-2-ene, Chemosphere, 38, 1205-1212.

Middleton, P., W. R. Stockwell, and W. P. L. Carter (1990), Aggregation and analysis of volatile organic compound emissions for regional modeling, Atmos. Environ., Part A, 24, 1107-1133.

Mihelcic, D., M. Heitlinger, D. Kley, P. Müsgen, and A. Volz-Thomas (1999), Formation of hydroxyl and hydroperoxy radicals in the gas-phase ozonolysis of ethene, Chem. Phys. Lett., 301, 559-564.

Nash, T. (1953), The colorimetric estimation of formaldehyde by means of the Hantzsch reaction, Biochem. J., 55, 416-421.

Neeb, P., and G. K. Moortgat (1999), Formation of OH radicals in the gasphase reaction of propene, isobutene, and isoprene with $\mathrm{O}_{3}$ : Yields and mechanistic implications, J. Phys. Chem. A, 103, 9003-9012.

Neeb, P., F. Sauer, O. Horie, and G. K. Moortgat (1997), Formation of hydroxymethyl hydroperoxide and formic acid in alkene ozonolysis in the presence of water vapour, Atmos. Environ., 31, 1417-1423.
Neeb, P., O. Horie, and G. K. Moortgat (1998), The ethene-ozone reaction in the gas phase, J. Phys. Chem. A, 102, 6778-6785.

Niki, H., P. D. Maker, C. M. Savage, and L. P. Breitenbach (1983), Atmospheric ozone-olefin reactions, Environ. Sci. Technol., 17, A312A322.

Niki, H., P. D. Maker, C. M. Savage, L. P. Breitenbach, and M. D. Hurley (1987), FTIR spectroscopic study of the mechanism for the gas-phase reaction between ozone and tetramethylethylene, J. Phys. Chem., 91, $941-946$.

Olzmann, M., E. Kraka, D. Cremer, R. Gutbrod, and S. Andersson (1997), Energetics, kinetics, and product distributions of the reactions of ozone with ethene and 2, 3-dimethyl-2-butene, J. Phys. Chem. A, 101, 94219429.

Paulson, S. E., R. C. Flagan, and J. H. Seinfeld (1992), Atmospheric photooxidation of isoprene part II: The ozone-isoprene reaction, Int. J. Chem. Kinet., 24, 103-125.

Paulson, S. E., M. Y. Chung, and A. S. Hasson (1999), OH radical formation from the gas-phase reaction of ozone with terminal alkenes and the relationship between structure and mechanism, J. Phys. Chem. A, 103, $8125-8138$

Rickard, A. R., D. Johnson, C. D. McGill, and G. Marston (1999), OH yields in the gas-phase reactions of ozone with alkenes, J. Phys. Chem. A, 103, 7656-7664.

Rodríguez Bares, S. (2003), Untersuchungen zur Ozonolyse einfacher Alkene in der Atmosphären-Simulationskammer SAPHIR, 194 pp., Forsch. Jülich, Jülich, Germany.

Rohrer, F., B. Bohn, T. Brauers, D. Brüning, F.-J. Johnen, A. Wahner, and J. Kleffmann (2005), Characterisation of the photolytic HONO-source in the atmosphere simulation chamber SAPHIR, Atmos. Chem. Phys., 5, $2189-2201$

Ryzhkov, A. B., and P. A. Ariya (2004), A theoretical study of the reactions of parent and substituted Criegee intermediates with water and the water dimer, Phys. Chem. Chem. Phys., 6, 5042-5050.

Sauer, F., C. Schäfer, P. Neeb, O. Horie, and G. K. Moortgat (1999), Formation of hydrogen peroxide in the ozonolysis of isoprene and simple alkenes under humid conditions, Atmos. Environ., 33, 229-241.

Siese, M., K. H. Becker, K. J. Brockmann, H. Geiger, A. Hofzumahaus, F. Holland, D. Mihelcic, and K. Wirtz (2001), Direct measurement of OH radicals from ozonolysis of selected alkenes: A EUPHORE simulation chamber study, Environ. Sci. Technol., 35, 4660-4667.

Stockwell, W. R., F. Kirchner, M. Kuhn, and S. Seefeld (1997), A new mechanism for regional atmospheric chemistry modeling, J. Geophys. Res., 102, 25,847-25,879.

Treacy, J., M. Elhag, D. Ofarrell, and H. Sidebottom (1992), Reactions of ozone with unsaturated organic compounds, Ber. Bunsenges., 96, 422427.

Tuazon, E. C., S. M. Aschmann, J. Arey, and R. Atkinson (1997), Products of the gas-phase reactions of $\mathrm{O}_{3}$ with a series of methyl-substituted ethenes, Environ. Sci. Technol., 31, 3004-3009.

T. Brauers, F. Rohrer, S. Rodríguez Bares, R. Tillmann, A. Wahner, and R. Wegener, Institut II: Troposphäre, Institut für Chemie und Dynamik der Geosphäre, Forschungszentrum Jülich, D-52425 Jülich, Germany. (r.wegener@fz-juelich.de)

A. Hansel and A. Wisthaler, Institut für Ionenphysik, Universität Innsbruck, Technikerstrasse 25, A-6020 Innsbruck, Austria.

R. Koppmann, Fachbereich C, Mathematik und Naturwissenschaften, Bergische Universität Wuppertal, Atmosphärenphysik Gaußstr. 20, D-42119 Wuppertal, Germany. 